\title{
Novel Electrochemical Treatment of Spent Caustic from the Hydrocarbon Industry Using Ti/BDD
}

\author{
Alejandro Medel, ${ }^{1}$ Erika Méndez, ${ }^{2}$ José L. Hernández-López, ${ }^{1}$ José A. Ramírez, ${ }^{1}$ \\ Jesús Cárdenas, ${ }^{1}$ Roberto F. Frausto, ${ }^{1}$ Luis A. Godínez, ${ }^{1}$ Erika Bustos, ${ }^{1}$ and Yunny Meas ${ }^{1}$ \\ ${ }^{1}$ Centro de Investigación y Desarrollo Tecnológico en Electroquímica, S.C., Parque Tecnológico, Querétaro-Sanfandila, \\ 76703 Pedro Escobedo, QRO, Mexico \\ ${ }^{2}$ Facultad de Ciencias Químicas, Laboratorio de Investigación Electroquímica, Universidad Autónoma de Puebla, \\ Ciudad Universitaria, Edificio 105-i., 72570 Puebla, PUE, Mexico
}

Correspondence should be addressed to Alejandro Medel; alejandromedelreyes@gmail.com and Yunny Meas; yunnymeas@cideteq.mx

Received 10 October 2014; Accepted 26 November 2014

Academic Editor: Mika Sillanpää

Copyright (C) 2015 Alejandro Medel et al. This is an open access article distributed under the Creative Commons Attribution License, which permits unrestricted use, distribution, and reproduction in any medium, provided the original work is properly cited.

\begin{abstract}
During the crude oil refining process, $\mathrm{NaOH}$ solutions are used to remove $\mathrm{H}_{2} \mathrm{~S}, \mathrm{H}_{2} \mathrm{~S}_{\mathrm{aq}}$, and sulfur compounds from different hydrocarbon streams. The residues obtained are called "spent caustics." These residues can be mixed with those obtained in other processes, adding to its chemical composition naphthenic acids and phenolic compounds, resulting in one of the most dangerous industrial residues. In this study, the use of electrochemical technology (ET), using BDD with Ti as substrate (Ti/BDD), is evaluated in electrolysis of spent caustic mixtures, obtained through individual samples from different refineries. In this way, the Ti/BDD's capability of carrying out the electrochemical destruction of spent caustics in an acidic medium is evaluated having as key process a chemical pretreatment phase. The potential production of ${ }^{\bullet} \mathrm{OHs}$, as the main reactive oxygen species electrogenerated over Ti/BDD surface, was evaluated in $\mathrm{HCl}$ and $\mathrm{H}_{2} \mathrm{SO}_{4}$ through fluorescence spectroscopy, demonstrating the reaction medium's influence on its production. The results show that the hydrocarbon industry spent caustics can be mineralized to $\mathrm{CO}_{2}$ and water, driving the use of ET and of the Ti/BDD to solve a real problem, whose potential and negative impact on the environment and on human health is and has been the environmental agencies' main focus.
\end{abstract}

\section{Introduction}

The aqueous residues produced by the hydrocarbon industry, which involve the use of sodium hydroxide $(\mathrm{NaOH})$ to remove hydrogen sulfide $\left(\mathrm{H}_{2} \mathrm{~S}\right)$, sulfhydric acid $\left(\mathrm{H}_{2} \mathrm{~S}_{\mathrm{aq}}\right)$, and sulfur compounds, found in different fractions of crude oil, are known as spent caustics. The process of producing said residues begins when an aqueous solution of $\mathrm{NaOH}$ is mixed with a fraction of oil. Although the oil itself can contain sulfur, the process is commonly carried out after the oil fraction is distilled, due to its contact with air, allowing the formation of $\mathrm{H}_{2} \mathrm{~S}$, which is very corrosive and difficult to remove. If the $\mathrm{H}_{2} \mathrm{~S}$ is formed, the $\mathrm{NaOH}$ reacts with it to form sodium sulfide, which is water soluble. The spent caustics are also obtained from different and specific processes, whereby they are classified as sulfidic spent caustics (removal of $\mathrm{H}_{2} \mathrm{~S}$ and mercaptans from hydrocarbons), naphthenics (removal of naphthenic acids from kerosene and diesel), and cresylic spent caustics (removal of organic acids, phenols, cresols, and xylenols). In the case of naphthenics and cresylics, the $\mathrm{NaOH}$ reacts with the naphthenic acids, leading to the formation of sodium naphthenates and phenolates, respectively. Accordingly and depending on the quantity and type of products processed, a refinery can generate spent caustics with multiple characteristics containing sulfide $\left(\mathrm{S}^{2-}, 1-\right.$ $4 \mathrm{wt} \%)$, mercaptans $(0.1-4 \mathrm{wt} \%)$, phenols $\left(0-2,000 \mathrm{mg} \mathrm{L}^{-1}\right)$, total organic carbon (TOC, 6,000-20,000 $\mathrm{mg} \mathrm{L}^{-1}$ ), chemical oxygen demand (COD, 20,000-60,000 $\mathrm{mg} \mathrm{L}^{-1}$ ), biochemical oxygen demand (BOD, $5,000-15,000 \mathrm{mg} \mathrm{L}^{-1}$ ), and potentially toxic elements (PTEs) such as $\mathrm{Cu}, \mathrm{Ni}, \mathrm{Cd}, \mathrm{Pb}$, and $\mathrm{Cr}$, among 
others [1], which require unconventional handling and treatment due to their highly toxic nature and unpleasant odor (the mercaptans can be detected in ppb). In the specific case of spent caustics produced from olefins plants, large amounts of $\mathrm{S}^{2-}\left(14,000-21,000 \mathrm{mg} \mathrm{L}^{-1}\right), \mathrm{pH}$ values of 13.5 to 13.7 , and emulsified hydrocarbons have also been reported [2]. With regard to the phenolic content, depending on the refining process, it can reach up to $30,600 \mathrm{mg} \mathrm{L}^{-1}$ [3]. The potential danger of the spent caustics can be understood considering the fact that, by not having technology for its treatment in situ, the different types of spent caustics can be combined, resulting in the production of highly toxic mixtures. On the other hand, when the spent caustics are not treated immediately, these are temporarily stored or confined by authorized companies, with their transport and storage being a latent threat due to the possibility of spillage, which has already been recorded in history with a highly negative impact on human health. A concentration of phenol ranging from 5 to $25 \mathrm{mg} \mathrm{L}^{-1}$ is as toxic for aquatic life as it is for humans $[4,5]$. For this reason, the maximum limits allowed of phenol residues found in industrial discharges vary between 0.5 and $1.0 \mathrm{mg} \mathrm{L}^{-1}$ [5]. In the case of potable drinking water, the European Union (EU), in its 80/778/EC Directive, assigned a maximum limit allowed of $<0.0005 \mathrm{mg} \mathrm{L}^{-1}$ for phenol in all of its forms [4], given that the consumption of water containing these compounds can induce cancer or death [6]. At the same time, the elevated danger of this contaminant for aquatic life has marked phenol and some phenolic compounds as priority contaminants, in agreement with the criteria of the Environmental Protection Agency (EPA) of the United States $[4,5]$. In a conventional manner, the treatment of spent caustics from refineries has been carried out in three steps: (1) wet air oxidation (WAO), (2) acid neutralization (AN), and (3) biological oxidation (BO). On occasions, step (2) can be followed by steam stripping. After AN, stripping removes residual $\mathrm{H}_{2} \mathrm{~S}$ and mercaptans. The liquid effluent obtained has high BOD and COD concentrations because the major portion of the organic constituents is unaffected by the stripping process. Although WAO can treat spent caustic to lower than $1,000 \mathrm{mg} \mathrm{L}^{-1} \mathrm{COD}$ in $60 \mathrm{~min}$ at $475 \mathrm{~K}$ and 28 bar, the process is very expensive, and due to severe reaction conditions, safety is a major concern [2]. At the same time, though the elimination of contaminants in steps (1) and (2) can lead to the obtainment of wastewater easily treatable by $\mathrm{BO}$, this depends strictly on the level of conversion and removal of the contaminants found. For example, if the sulfur content is high and the concentration of phenols is low, the $\mathrm{BO}$ (use of bacteria from the genus Thiobacillus) is possible. Contrarily, the process can be deactivated when the concentration of phenol is high. It has been reported that effluents containing phenol with a concentration of $>3000 \mathrm{mg} \mathrm{L}^{-1}$ cannot be treated through BO [4]. Taking this problem into account, different processes have been applied and evaluated for the treatment of effluents from refineries, leaving aside the treatment of the spent caustics. It is important to mention that the physicochemical nature and composition of the spent caustics is not comparable to wastewater produced as part of the extraction processes of crude oil (water produced) or the wastewater produced in other processes. In spent caustics the content of phenolic compounds can reach a value of $30,600 \mathrm{mg} \mathrm{L}^{-1}$ [3], while in water produced or any other kind of wastewater this value can oscillate between 20 and $200 \mathrm{mg} \mathrm{L}^{-1}$ [7-9]. In the case of wastewaters from refineries, the chemical coagulation using polyaluminium chloride [10], chemical precipitation [11], integrated processes (coagulation-flocculation and flotation) [12], and electrocoagulation (EC) has been reported to remove the high content of the organic material found [13]. At the same time and considering the importance of the phenolic content, as well as the content of commonly found fats and oils [14], the EC has also been evaluated, using $\mathrm{NaCl}$, reaching removal percentages of $91 \%$ [15] and $94.5 \%$ [16] for synthetic and real samples, respectively. In other studies, the combination of electroflotation (EF) and EC and integrated processes (ECadsorption-BO) have also been proposed $[17,18]$. Although, in spent caustics, the EC has been tested for the removal of sulfides and organic material [1], it is important to highlight that the nature of this process is not destructive, allowing the transference of the pollutants from one phase to another with the subsequent disposal problem. On the other hand and considering the technical difficulties in treating aqueous wastes containing phenol or phenolic compounds through WAO, $\mathrm{BO}$ or EC, alternative processes of a destructive nature such as the chemical advanced oxidation processes (AOPs, in the presence or absence of sunlight or assisted light), like the use of hydrogen peroxide $\left(\mathrm{H}_{2} \mathrm{O}_{2}\right)$, ozone $\left(\mathrm{O}_{3}\right)$, photocatalysis, Fenton process, and the ozonation in alkaline medium, have been amply tested in the treatment of phenols and phenolic compounds. However, the majority of these studies have only been carried out on synthetic samples. In real samples from refineries, applying these processes, only a few studies have been reported [19]. Considering the importance implied in the treatment of real samples, in the last years (20002014), different isolated studies have been reported on the treatment of spent caustics using the Fenton process. In this sense, samples containing a COD of $20,160 \mathrm{mg} \mathrm{L}^{-1}$ and a total of phenols of $1,800 \mathrm{mg} \mathrm{L}^{-1}$ have been successfully treated obtaining removal efficiencies of $90 \%$ for COD and $99 \%$ for total phenols at a $\mathrm{pH}$ of 4 [20]. At the same time, when comparing this process using assisted light (photo-Fenton) in the treatment of sulfidic spent caustics, a greater efficiency was reached with a removal of COD and sulfide up to $97 \%$ and $100 \%$, respectively [21]. Applying both processes and despite the excellent results, in practice, the percentage of total destruction of the organic content is strictly dependent on the physicochemical composition of the sample to be treated. An elevated organic charge consumes a large amount of $\mathrm{H}_{2} \mathrm{O}_{2}$. Also, because of a high concentration of $\mathrm{H}_{2} \mathrm{~S}$ (up to $20 \mathrm{~g} \mathrm{~L}^{-1}$ ), its reaction with ferric ion causes a loss of iron catalyst activity [2]. At the same time, it is necessary to emphasize that the chemical AOPs do not possess the ability to destroy the reaction byproducts. Contrarily, one of the most efficient processes and with the potential to carry out the destruction of any contaminant, including phenol and phenolic compounds, is electrochemical oxidation (EO). Said technology bases its efficiency on the nature of 
the material used as anode [22]. In this sense, two types of anodic materials are known: (i) active anodes ( $\mathrm{Au}, \mathrm{Ni}$, stainless steel (SS), $\mathrm{Pt}, \mathrm{IrO}_{2}, \mathrm{Ti} / \mathrm{RuO}_{2}$, and analogous combinations) and, (ii) inactive anodes $\left(\mathrm{Ti} / \mathrm{PbO}_{2}, \mathrm{Ti} / \mathrm{SnO}_{2}-\mathrm{Sb}\right.$, and analogous combinations), which are materials with a low or high production of ${ }^{\bullet} \mathrm{OH}$ radicals $\left({ }^{\circ} \mathrm{OHs}\right)$, respectively. The - OHs can destroy any toxic pollutant to $\mathrm{CO}_{2}$ and water, due to its high oxidation potential ( $2.8 \mathrm{~V}$ vs. $\mathrm{ENH})$. For this reason the use of inactive anodes is preferred. Here, it is important to mention that $\mathrm{Au}, \mathrm{Ni}, \mathrm{SS}, \mathrm{Pt}$, and analogous combinations are included, due to their similar active or inactive behavior. These materials are not included in the original reference. Although, in the literature, there are numerous studies related to the EO of phenol in synthetic samples [22-53], only a few studies have been reported applying this technology in the treatment of samples from refineries and, as far as we know, there are no reported studies on the treatment of spent caustics. It is also important to consider that both types of aqueous residues represent a highly complex matrix, whose chemical composition can favor or diminish the process efficiency. According to this, using a titanium (Ti) electrode, coated with titanium oxide and ruthenium oxide $\left(\mathrm{RuO}_{2}\right)$, efficiencies of phenol degradation in $99.7 \%$ and $94.5 \%$ and oxidation percentages of COD in $88.9 \%$ and $70.1 \%$ were obtained for synthetic and real samples (petroleum refinery wastewater), respectively [54]. In other studies using $\mathrm{Ti} / \mathrm{TiO}_{2}-\mathrm{RuO}_{2}-\mathrm{IrO}_{2}$ for phenol degradation in wastewater samples from refineries, removal percentages of $74.75 \%$ and $48 \%$ for COD and TOC, respectively, were obtained, even when using high quantities of chloride ions [7]. At the same time, the use of $\mathrm{Ti} / \mathrm{RuO} \mathrm{O}_{2}-\mathrm{TiO}_{2}-\mathrm{SnO}_{2}$ has also been evaluated in the hydrocarbon industry effluents, obtaining low percentages of phenol degradation around 20-47\% [55]. Ruling out the use of active electrodes and mixtures of these [56], a very important option is the use of $\mathrm{Ti} / \mathrm{SnO}_{2}$ $\mathrm{Sb}$ and $\mathrm{Ti} / \mathrm{PbO}_{2}$, which possess a high production of ${ }^{\circ} \mathrm{OHs}$; however, the application of these materials continues to be restricted due to structural problems and to the possible release of $\mathrm{Pb}$ ions [57-59]. As an alternative anodic material, the boron doped diamond (BDD) has been amply evaluated and accepted due to its unusual properties such as a high corrosion resistance, a low adsorption of organic compounds, generation of oxidizing species $\left(\mathrm{O}_{3}, \mathrm{H}_{2} \mathrm{O}_{2}\right.$, and $\left.{ }^{\circ} \mathrm{OH}\right)$ [60], and an elevated overpotential for the reaction of oxygen evolution, $\eta \mathrm{O}_{2}$ [61]. The BDD efficiency is based on its high production of ${ }^{\bullet} \mathrm{OHs}$, which are produced through the water oxidation process (1), leading to the complete mineralization of pollutants to $\mathrm{CO}_{2}$ and water (2), with high current efficiencies [62]. This process is known as electrochemical incineration [22]:

$$
\begin{gathered}
\mathrm{H}_{2} \mathrm{O} \longrightarrow{ }^{\cdot} \mathrm{OH}+\mathrm{H}^{+}+\mathrm{e}^{-} \\
\mathrm{R}+\mathrm{M}\left({ }^{\bullet} \mathrm{OH}\right) \longrightarrow \mathrm{M}+m \mathrm{CO}_{2}+n \mathrm{H}_{2} \mathrm{O}+\mathrm{H}^{+}+\mathrm{e}^{-}
\end{gathered}
$$

It is important to emphasize that different studies on the oxidation of phenol and phenolic compounds in synthetic samples, using BDD, have been presented from 2000 to 2014 [63-86], demonstrating the capability of the use of BDD for the destruction of these pollutants. When comparing the use of $\mathrm{Ti} / \mathrm{BDD}$ with $\mathrm{Ti} / \mathrm{SnO}_{2}-\mathrm{Sb}[87,88]$ and $\mathrm{PbO}_{2}$ [89], it was found that the $\mathrm{BDD}$ electrode is much better for the destruction of phenol. Although the application of BDD in real samples has been weakly explored, when comparing the $\mathrm{BDD}$ with the electro-Fenton process for the treatment of wastewaters from refineries, it has been confirmed that even though the electro-Fenton process can induce a greater phenol degradation in comparison with the BDD electrode, the greater efficiency of degradation of the reaction byproducts (in terms of COD and TOC) occurs with $\operatorname{BDD}[9,90]$. At the same time, other important studies applying the BDD for the treatment of water produced and typical wastewater from refineries have demonstrated the great efficiency of BDD [9193]. Said studies and those previously presented not only highlight the effectiveness of the use of the electrochemical technology using BDD but also represent a platform which impulses the use of the BDD, whose scaling potential must be examined in order to advance strategically in solving real problems. According to the above, and based on an extensive review of specialized literature from 1980 to 2014 (use of national and international databases), the object of the present study is to demonstrate the technical feasibility of the use of the Ti/BDD in the electrochemical treatment of spent caustics mixtures, one of the most toxic residues at an industrial level, whose potential and negative impact on the environment and human health is and has been the main focus of environmental agencies.

\section{Experimental Details}

2.1. Chemicals. Sulfuric acid $\left(\mathrm{H}_{2} \mathrm{SO}_{4}\right)$, hydrochloric acid $(\mathrm{HCl}), \mathrm{NaOH}$, and phenol $\left(\mathrm{C}_{6} \mathrm{H}_{5} \mathrm{OH}\right)$ were obtained from J. T. Baker. $\mathrm{K}_{2} \mathrm{HPO}_{4}, \mathrm{KH}_{2} \mathrm{PO}_{4}, \mathrm{NH}_{4} \mathrm{OH}$, potassium ferricyanide $\left(\mathrm{K}_{3} \mathrm{Fe}(\mathrm{CN})_{6}\right)$, and 4-aminoantipyrine $\left(\mathrm{C}_{11} \mathrm{H}_{13} \mathrm{~N}_{3} \mathrm{O}\right)$ for analysis of phenol in all of its forms were obtained from Aldrich. Coumarin was obtained from Aldrich. The luminescent marine bacteria Vibrio fischeri (Photobacterium phosphoreum) for toxicity analysis was provided by SDI.

2.2. Instruments. Analysis of phenol in all of its forms was carried out through visible ultraviolet spectroscopy (UVVis), using a Lambda $\mathrm{XLS}^{+}$spectrophotometer. COD and TOC were evaluated using a Hach model DR/200 reactor/UvVis spectrophotometer DR/2010 and Shimadzu Model TOCVCSN equipment, respectively. COD was obtained using $\mathrm{HACH}$ products. Toxicity analysis was done using a DeltaTox kit, provided by SDI. Electrolysis using ultraviolet light $(\lambda=254 \mathrm{~nm})$ was done by using a Philips mercury lamp with $11 \mathrm{~W}$. Orion Star A215 equipment was used for $\mathrm{pH} /$ $\mathrm{ORP} /$ conductivity measurements. The electrolysis experiments in galvanostatic mode were performed using Tektronix PWS4323 equipment. The PTEs analyses were performed using a Perkin Elmer Optima 3300 DV model and an Analyst 200/MHS-15 Perkin Elmer. The first equipment was used for the inductively coupled plasma (ICP) analysis and the second for the $\mathrm{Hg}$ analyses by hydride generation. The morphology and element analysis of the different electrodes evaluated during the selection of the best anodic material were obtained using a scanning electron microscope (JEOL JMS-6060LV) 


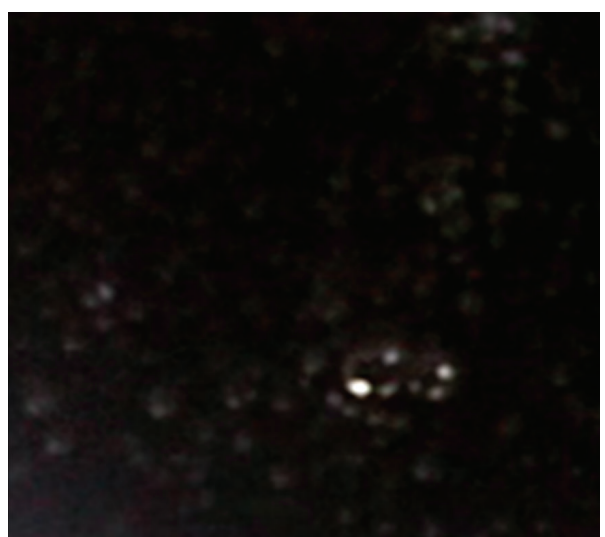

(a)

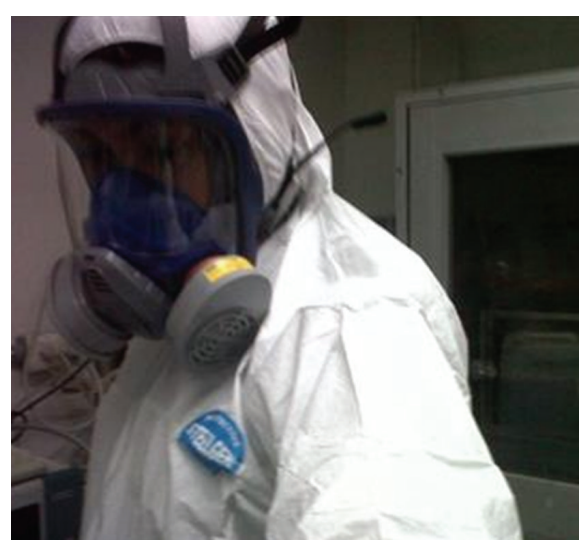

(b)

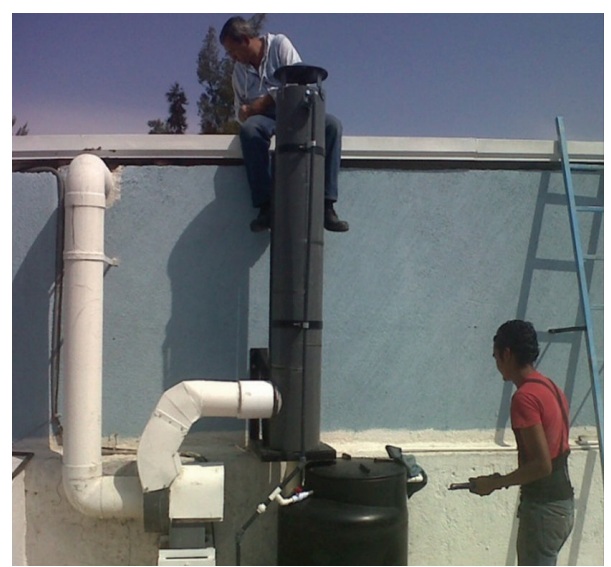

(c)

FIgURE 1: Handling and control of (a) spent caustics mixture, (b) safety equipment, and (c) specialized infrastructure.

equipped with an energy dispersive spectrometer (EDS). Crystal structure analysis using X-ray diffraction (XRD) was carried out in a Rigaku Minifles, using $\mathrm{Cu} \mathrm{K} \alpha$ radiation, with a $30 \mathrm{kV}$ operation voltage and $15 \mathrm{~mA}$ of current, at a velocity of $2^{\circ} / \mathrm{min}$. Cyclic voltammetry $(\mathrm{CV})$ was carried out with an Autolab PGSTAT 30 . The ${ }^{\circ} \mathrm{OH}$ analysis was performed by fluorescence spectroscopy using the equipment HORIBA Jobin MOD Fluorolog 3-22 with double monochromator.

\subsection{Characterization of the Spent Caustics}

2.3.1. Sample Preparation. A total of 10 samples $(20 \mathrm{~L}$ each) of spent caustic were obtained from different refineries and stored at room temperature. From these samples, a composite sample was prepared by combining $1 \mathrm{~L}$ of each individual sample. The sample obtained (called mixture) is shown in Figure 1(a). This process was carried out using safety equipment (Figure 1(b)) and working under an exhaust hood, which was attached to a gas scrubber containing $\mathrm{NaOH}$ (Figure 1(c))

Before taking each sample, the container was stirred vigorously and the sample was taken immediately. The mixture obtained was also stirred vigorously and stored under refrigeration $\left(4^{\circ} \mathrm{C}\right)$ until its analysis.
2.3.2. Physicochemical Analysis. Before carrying out any analysis, the container of the mixture of spent caustics was stirred vigorously. The PTEs analysis was done by using inductively coupled plasma atomic emission spectroscopy (ICP-AES), with the exception of $\mathrm{Hg}$, which was analyzed by hydride generation atomic absorption spectroscopy (HGAAS). The analysis was done prior to digestion of the samples. The concentration of anions present was done through ion chromatography according to the EPA method 300.1 (EPA, 1997). This analysis was performed using a high resolution liquid chromatograph Dionex ICS-2500 HPLC/IC fitted with a Dionex IonPac AS14A column and coupled to a conductivity detector (ED50A). The mobile phase was $\mathrm{Na}_{2} \mathrm{CO}_{3} / \mathrm{NaHCO}_{3}$ $\left(1 \mathrm{~mL} \mathrm{~min}{ }^{-1}\right)$. The equipment was calibrated using prepared solutions from the 7-Anion Standard of Dionex and the quality of the results was evaluated from the analysis of the certified standard of Inorganic Ventures IC-FAS-1A. The determination of volatile and semivolatile organic compounds (CIDETEQ and Intertek laboratories) in qualitative form was done through gas chromatography mass spectrometry (GC-MS) in accordance with the EPA 5030/EPA 8260C2006 and EPA 3510/EPA 8270D-2007 procedures. Other physicochemical analyses were done under standard procedures. It is important to highlight that, during the entire 


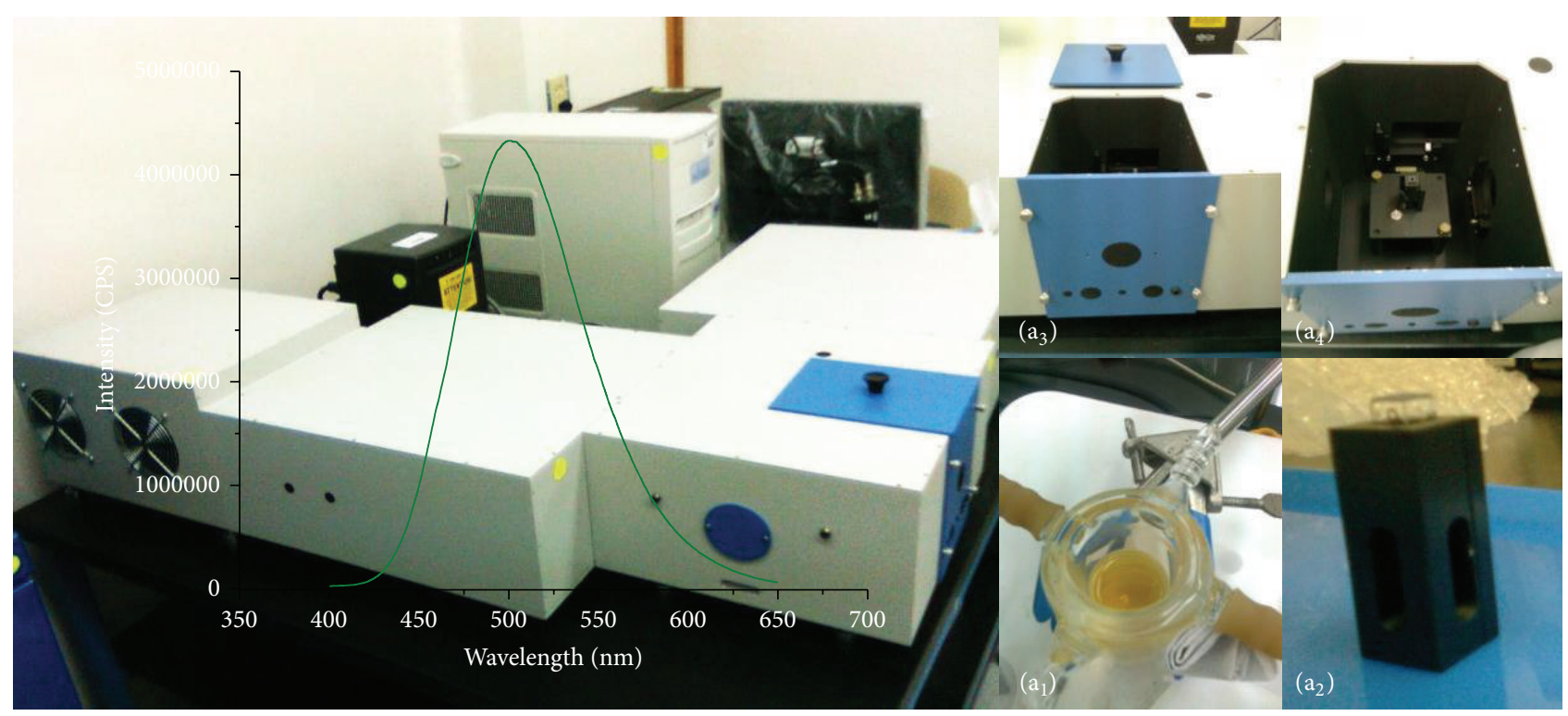

(a)

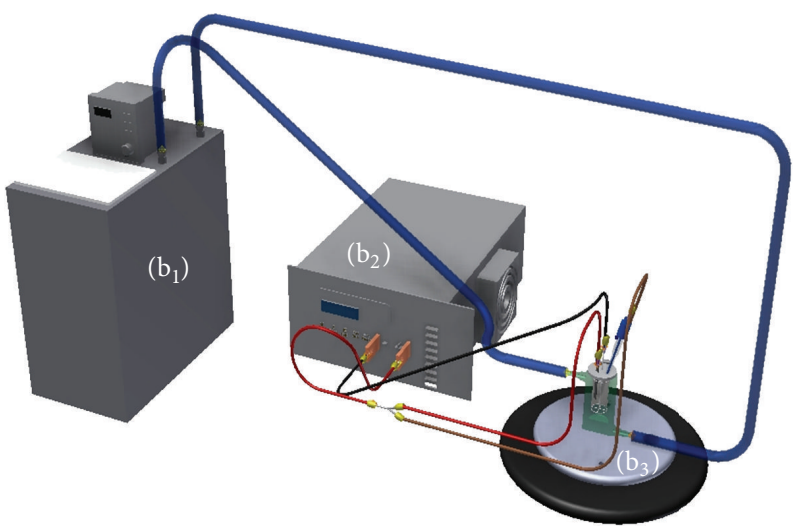

(b)

FIGURE 2: Experimental system for (a) hydroxyl radicals' analysis by fluorescence spectroscopy, where $\left(\mathrm{a}_{1}\right)-\left(\mathrm{a}_{4}\right)$ are the steps for analysis of 7-hydroxycoumarin, and (b) electrolysis in galvanostatic mode of spent caustics mixture using Ti/BDD: $\left(b_{1}\right)$ heat exchanger, $\left(b_{2}\right)$ rectifier, and $\left(b_{3}\right)$ electrochemical cell.

process of preparation and analysis of the samples, a strict security protocol was followed, from the use of a personalized infrastructure and safety equipment such as gas masks, nitrile, and neoprene gloves, to that of a special suit.

\subsection{Electrochemical Treatment}

2.4.1. Selection of the Anode. Morphological, structural, and electrochemical analysis of the different materials evaluated $\left(\mathrm{Ti} / \mathrm{IrO}_{2}-\mathrm{Ta}_{2} \mathrm{O}_{5}, \mathrm{Ti} / \mathrm{SnO}_{2}-\mathrm{Sb}\right.$, and $\left.\mathrm{Ti} / \mathrm{BDD}\right)$ by SEM-EDS, $\mathrm{XRD}$, and CV were done over the same area $\left(2.185 \mathrm{~cm}^{2}\right)$. $\mathrm{Ti} / \mathrm{IrO}_{2}-\mathrm{Ta}_{2} \mathrm{O}_{5}$ and $\mathrm{Ti} / \mathrm{SnO}_{2}$-Sb electrodes were synthesized by the thermal deposition method using a special formulation. Polycrystalline boron $((\mathrm{B})=1300 \mathrm{ppm})$ doped diamond film (Ti/BDD) of $3 \mu \mathrm{m}$ thickness, provided by Adamant Technologies, was synthesized by hot filament chemical vapor deposition (HF-CVD). The electroactivity of each material was evaluated by CV using a three-electrode cell $(60 \mathrm{~mL}$ capacity, with a reaction volume of $50 \mathrm{~mL}$ ). $\mathrm{Ti} / \mathrm{IrO}_{2}-\mathrm{Ta}_{2} \mathrm{O}_{5}$, $\mathrm{Ti} / \mathrm{SnO}_{2}-\mathrm{Sb}$, and $\mathrm{Ti} / \mathrm{BDD}$ electrodes $\left(2.185 \mathrm{~cm}^{2}\right)$ were used as anodes, a rod of $\mathrm{Ti}$ was used as cathode, and a mercury sulfate electrode $\left(\mathrm{Hg} / \mathrm{Hg}_{2} \mathrm{SO}_{4} / \mathrm{K}_{2} \mathrm{SO}_{4}(\mathrm{SAT}), E^{\circ}=0.640 \mathrm{~V}\right.$ vs. SHE) was the reference electrode. The temperature was maintained at $298 \mathrm{~K}$ and the voltammetric profiles for each electrode were obtained applying a scan rate of $100 \mathrm{mV} \mathrm{s}^{-1}$ using $0.5 \mathrm{M} \mathrm{H}_{2} \mathrm{SO}_{4}$ as the supporting electrolyte. Before each analysis, the system was deoxygenated using $\mathrm{N}_{2}$ gas. In this analysis the $\mathrm{Ti} / \mathrm{BDD}$ was previously activated (to eliminate C-sp ${ }^{2}$ impurities) developing a special methodology [94]. $\mathrm{Ti} / \mathrm{IrO}_{2}-\mathrm{Ta}_{2} \mathrm{O}_{5}$ and $\mathrm{Ti} / \mathrm{SnO}_{2}$-Sb were activated by cycling each electrode ( 50 cycles, $100 \mathrm{mV} \mathrm{s}^{-1}$ in $0.5 \mathrm{M} \mathrm{H}_{2} \mathrm{SO}_{4}$ ) to stabilize the surface and eliminate impurities.

2.4.2. Selection of the Reaction Medium. Three aspects were taken into account: (i) the $\mathrm{pH}$ effect on the chemical state of 
phenol, (ii) the $\mathrm{pH}$ effect on the electrochemical response of the previously selected electrode, and (iii) the $\mathrm{pH}$ effect on the production of ${ }^{\bullet} \mathrm{OHs}$. In the first point, analysis by UV-Vis spectroscopy to different $\mathrm{pH}$ values was performed with the goal of identifying possible chemical changes on the phenol structure. In this analysis, a synthetic sample was used. The second point was evaluated by the use of $\mathrm{CV}$ analyzing two types of acids, $\mathrm{HCl}$ and $\mathrm{H}_{2} \mathrm{SO}_{4}(0.5 \mathrm{M})$, under the same conditions mentioned above. The last point was evaluated through electrolysis experiments, which were performed applying an anodic potential pulse $\left(2.3 \mathrm{~V}\right.$ vs. $\mathrm{Hg} / \mathrm{Hg}_{2} \mathrm{SO}_{4}$, polarization time of $10 \mathrm{~min}$, use of a Pt mesh as counter electrode, $298 \mathrm{~K}$ ). This last analysis was performed through the use of fluorescence spectroscopy using coumarin $(3 \times$ $10^{-5} \mathrm{M}$ ) as a probe compound to give way to the formation of the 7-hydroxycoumarin with a wavelength of maximum excitation and emission of $332 \mathrm{~nm}$ and $500 \mathrm{~nm}$, respectively $\left(\lambda_{\text {ex }}=332 \mathrm{~nm}, \lambda_{\text {em }}=500 \mathrm{~nm}\right)$. During electrolysis, samples of $10 \mu \mathrm{L}$ were withdrawn every minute and immediately analyzed. The equipment and the cell used for detection of the 7-hydroxycoumarin are shown in Figure 2(a).

2.4.3. Electrolysis of the Spent Caustic. The electrochemical destruction process of the mixture of spent caustics was done in galvanostatic mode, using the experimental system shown in Figure 2(b). In this process, a cell with a single compartment and a capacity of $120 \mathrm{~mL}$ (reaction volume of $100 \mathrm{~mL}, 8 \mathrm{rpm}, 298 \mathrm{~K}$ and Ti/ $\mathrm{Pt}\left(3 \mathrm{~cm}^{2}\right.$ as counter electrode) $)$ was used. The area of the anode (prior selection) was $3 \mathrm{~cm}^{2}$. Electrolysis with UV light $(\lambda=254 \mathrm{~nm})$ was done under the same conditions indicated above. In each experiment, representative samples were taken at different reaction times $\left(t_{r}\right)$, and the degradation of aromatic compounds (phenol and phenolic compounds) and reaction intermediates was done through TOC and COD analysis.

The removal percentages were calculated according to the following formula (3), where $C_{o}$ is the initial concentration $\left(\mathrm{mg} \mathrm{L}^{-1}\right)$ and $C_{f}$ is the final concentration $\left(\mathrm{mg} \mathrm{L}^{-1}\right)$ [90]:

$$
\% \text { removal }=\left[\frac{\left(C_{o}-C_{f}\right)}{C_{o}}\right] * 100 .
$$

The phenol analysis was done using a standard procedure [95], while the toxicity tests were done using a standard method using a lyophilized bacteria, Vibrio Fischeri (Photobacterium phosphoreum), of a luminescent nature, where the reduction of light is proportional to the degree of toxicity.

\section{Results}

\subsection{Characterization of the Spent Caustics}

3.1.1. Physicochemical Analysis. Table 1 shows the results obtained in the physicochemical characterization of the sample corresponding to the mixture of spent caustics (mixture of 10 samples). Comparatively, it shows the analysis of a simple sample, corresponding to the sample of greater toxicity (preliminary evaluation of the phenolic content), including the reported values in the literature for spent caustics as well as for wastewater from refineries [1, 3, 7, 9, 13, 16-19, 96-98].

The analysis of the mixture showed a phenolic content of $11,041.74 \mathrm{mg} \mathrm{L}^{-1}$, while the simple sample showed a content of $7,270.89 \mathrm{mg} \mathrm{L}^{-1}$. The difference between both samples clearly demonstrates the environmental problem that commonly appears in the hydrocarbon industry. That is to say, residues of low or high toxicity are mixed with each other, resulting in a residue of greater toxicity. Here, the phenol concentration, organic load, and dissolved solids are not comparable with any other residue, including wastewater from different refining processes [90]. The phenol concentration in the samples analyzed suggest that this residue cannot be treated by $\mathrm{BO}$ (a concentration $>3,000 \mathrm{mg} \mathrm{L}^{-1}$ leads to the complete deactivation of the microorganisms). This is confirmed by the result obtained in the toxicity tests $(100 \%$ toxic) and through the analysis of the $\mathrm{BOD}_{5} / \mathrm{COD}=0.09$ and 0.07 for the simple sample and the sample corresponding to the mixture, respectively. On the other hand, the elevated alkalinity $\left(52,266.35 \mathrm{mg} \mathrm{L}^{-1}\right)$ and an elevated $\mathrm{pH}(13-13.5)$ reflect the reducing nature of these residues, which should be considered in the treatment to be chosen. Many of the contaminants can be fixed at an alkaline $\mathrm{pH}$ and be liberated under oxidizing conditions. The reactivity analysis for sulphides and cyanides showed values below the detection limit ( $<37.29$ and $<0.25 \mathrm{mg} \mathrm{L}^{-1}$, resp.). Based on the results obtained in this phase of characterization, the samples evaluated were classified as cresylic spent caustics.

3.1.2. Ion Analysis. The analysis of anions, done through ion chromatography, in the case of the simple sample, showed a low content of chlorides $\left(\mathrm{Cl}^{-}\right)$and sulfates $\left(\mathrm{SO}_{4}{ }^{-2}\right)$ with values of 86 and $608 \mathrm{mg} \mathrm{L}^{-1}$, respectively, with their concentration being much higher in the mixture, with values of 54,900 and $1,882 \mathrm{mg} \mathrm{L}^{-1}$, respectively. It is necessary to mention that in this case the presence of chlorides is very important. The chlorides, while they can give rise to the presence of compounds of greater toxicity, can also exert a synergic effect during an EO process, giving way to the formation of different oxidizing species $[99,100]$.

3.1.3. Analysis of Volatile and Semivolatile Organic Compounds. An analysis through GC-MS, corresponding to the mixture of spent caustics, was carried out to determine the different phenolic compounds (reflected in the analysis of phenol in all of its forms, Table 1). Different compounds were considered, of which 43 were for volatile and 62 for semivolatile analysis. The results showed only the presence of 2,4-dimethylphenol, phenol, m-methylphenol, pmethylphenol, and o-methylphenol, all highly toxic compounds. Figure 3 shows the representative chemical structures of each compound identified.

At the same time, a PTEs analysis through ICP was carried out, taking into account that the physicochemical composition of the mixture of spent caustics includes PTEs and possible catalyst traces used in the different processes of hydrocarbon refining. The selection of each PTE was based on an extensive bibliography review. Table 2 shows the main 
TABle 1: Physicochemical analysis of spent caustics.

\begin{tabular}{|c|c|c|c|c|}
\hline \multirow{2}{*}{ Parameter } & \multicolumn{2}{|c|}{ Value } & \multicolumn{2}{|r|}{ Value reference } \\
\hline & $\begin{array}{l}\text { Simple } \\
\text { sample }\end{array}$ & Mixture & Spent caustic & Typical refinery wastewater \\
\hline Total phenol (mg L $\left.\mathrm{m}^{-1}\right)$ & $7,270.89$ & $11,041.74$ & $30,600[3]$ & $\begin{array}{c}13[16], 172.50[18], 3.17[17], 192.90[9], 141[7], 113 \\
{[19], 23[96]}\end{array}$ \\
\hline Oil and grease $\left(\mathrm{mg} \mathrm{L}^{-1}\right)$ & 239.70 & $3,399.70$ & - & $85[97], 1.96[17], 12.70[19], 15[98]$ \\
\hline $\mathrm{BOD}_{5}\left(\mathrm{mg} \mathrm{L}^{-1}\right)$ & 6,930 & 7,811 & - & $323[97], 40.25[16], 570[3]$ \\
\hline $\mathrm{COD}\left(\mathrm{mg} \mathrm{O}_{2} \mathrm{~L}^{-1}\right)$ & 72,065 & $\begin{array}{c}98,750- \\
102,842.50\end{array}$ & $72,450[1], 320,100[3]$ & $\begin{array}{c}3,150[97], 100[16], 4,450[18], 2,323[13], 257[17] \\
590[9], 602[7], 935[19], 2,746[98], 1,220[96]\end{array}$ \\
\hline $\mathrm{BOD}_{5} / \mathrm{COD}$ & 0.09 & 0.07 & - & $0.60[19]$ \\
\hline Sulfides $\left(\mathrm{mg} \mathrm{L}^{-1}\right)$ & $<37.29$ & $<37.29$ & $34,517[1], 48,500[3]$ & $19[19]$ \\
\hline Ammonia $\left(\mathrm{mg} \mathrm{L}^{-1}\right)$ & - & - & - & $13.10[19]$ \\
\hline Cyanides $\left(\mathrm{mg} \mathrm{L}^{-1}\right)$ & $<0.25$ & $<0.25$ & - & - \\
\hline $\mathrm{pH}$ & 13.02 & 13.50 & $12.97[1], 13[3]$ & $\begin{array}{c}8[16], 8.60[18], 8.05[13], 7.60[17], 9.20[7], 8.10 \\
{[19], 7.59[98], 10[96]}\end{array}$ \\
\hline $\operatorname{TOC}\left(\mathrm{mg} \mathrm{L}^{-1}\right)$ & - & $20,137.50$ & $53,900[3]$ & $370[19], 1,500[96]$ \\
\hline Hydrocarbons $\left(\mathrm{mg} \mathrm{L}^{-1}\right)$ & - & - & - & $11.72[17], 0.02[19]$ \\
\hline Conductivity $\left(\mathrm{mS} \mathrm{cm}^{-1}\right)$ & 129.20 & 208.44 & $126.70[1]$ & $6[18], 13.06[13], 15.63[7], 1.73[7], 0.06[98]$ \\
\hline Alkalinity, $\mathrm{CaCO}_{3}\left(\mathrm{mg} \mathrm{L}^{-1}\right)$ & $52,266.35$ & - & $15,500[3]$ & $3,990[96]$ \\
\hline Total dissolved solid $\left(\mathrm{mg} \mathrm{L}^{-1}\right)$ & - & 169,680 & - & $5,000[18], 7,990[13], 1,333[7], 4,380[98]$ \\
\hline $\begin{array}{l}\text { Settleable solids } \\
\left(\mathrm{mg} \mathrm{L}^{-1}\right)\end{array}$ & - & 40 & - & 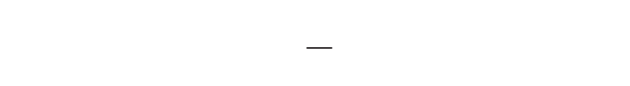 \\
\hline $\begin{array}{l}\text { Total suspended solids } \\
\left(\mathrm{mg} \mathrm{L}^{-1}\right)\end{array}$ & - & 3,940 & - & $22.80[16], 35[18], 100[13], 1,000[96]$ \\
\hline Toxicity (\%) & 100 & 100 & - & - \\
\hline $\mathrm{F}^{-}\left(\mathrm{mg} \mathrm{L}^{-1}\right)$ & 50 & 135 & - & - \\
\hline $\mathrm{Cl}^{-}\left(\mathrm{mg} \mathrm{L}^{-1}\right)$ & 86 & 54,900 & $37,900[3]$ & 63 [97], 112 [7], 200,000 [96] \\
\hline $\mathrm{Br}^{-}\left(\mathrm{mg} \mathrm{L}^{-1}\right)$ & 12 & $<0.30$ & - & - \\
\hline $\mathrm{NO}_{3}^{-}\left(\mathrm{mg} \mathrm{L}^{-1}\right)$ & 11 & $<0.25$ & - & - \\
\hline $\mathrm{PO}_{4}^{3-}\left(\mathrm{mg} \mathrm{L}^{-1}\right)$ & 381 & $<0.30$ & $4,600[3]$ & - \\
\hline $\mathrm{SO}_{4}^{2-}\left(\mathrm{mg} \mathrm{L}^{-1}\right)$ & 608 & 1,882 & $20,300[3]$ & $1,054.50[13], 212[7], 1,650[96]$ \\
\hline ORP $(\mathrm{mV})$ & -334.20 & - & - & - \\
\hline Turbidity (NTU) & - & - & - & $6.10[16], 37[17], 37$ [19] \\
\hline
\end{tabular}

PTEs identified in the mixture sample. In this analysis, a high amount of $\mathrm{Na}^{+}$and $\mathrm{Fe}$ with values of $19,148 \mathrm{mg} \mathrm{L}^{-1}$ and $1,323 \mathrm{mg} \mathrm{L}^{-1}$, respectively, was identified. The presence of $\mathrm{Na}^{+}$confirms the caustic nature of the sample, while the presence of $\mathrm{Fe}$, though it is not an especially toxic element, is commonly controlled by the effect of turbidity caused by the precipitation of oxides and hydroxides. The analysis of $\mathrm{Fe}$ was done taking into account its catalytic activity on $\mathrm{H}_{2} \mathrm{O}_{2}$, to give way for the ${ }^{\bullet} \mathrm{OH}$ through the Fenton reaction [90]. Due to this, the presence of Fe could be used to accelerate the mineralization process and decrease the residence times during the EO process.

On the other hand, PTEs like As and $\mathrm{Cd}$ remained under the detection limit $\left(<0.098\right.$ and $<0.114 \mathrm{mg} \mathrm{L}^{-1}$, resp.), while $\mathrm{Cu}, \mathrm{Cr}, \mathrm{Hg}, \mathrm{Ni}$, and $\mathrm{Pb}$ exceeded the maximum limits allowed under the Mexican Regulation [101]. It is important to highlight the elevated toxicity of said elements and, specially, that of the $\mathrm{Hg}[102,103]$ and $\mathrm{Pb}$, which have the ability to enter into the food chains and to concentrate in organisms (magnification process). Considering these analyses, the elevated toxicity of the spent caustics is confirmed, thus justifying the need to direct efforts towards their treatment and/or destruction.

\subsection{Electrochemical Treatment}

3.2.1. Selection of the Anode. Morphology, elemental composition, crystal structure, and electrochemical analysis. The results corresponding to these analyses are shown in Figure 4. The morphology of metal oxide coatings $\left(\mathrm{Ti} / \mathrm{IrO}_{2}-\mathrm{Ta}_{2} \mathrm{O}_{5}\right.$ and $\mathrm{Ti} / \mathrm{SnO}_{2}-\mathrm{Sb}$ ) (Figures 4(a) and 4(b), resp.) showed smaller cracks in comparison with Ti/BDD (Figure 4(c)). The latter showed a compact structure, demonstrating the quality of the coating and the adherence of the diamond to the titanium substrate. In parallel, X-ray dot-mapping was used to analyze the distribution of coating elements. 
TABle 2: Analysis of PTEs in spent caustics mixture.

\begin{tabular}{|c|c|c|c|c|c|c|c|}
\hline \multirow{3}{*}{\multicolumn{2}{|c|}{$\mathrm{PTE}\left(\mathrm{mg} \mathrm{L}^{-1}\right)$}} & \multicolumn{6}{|c|}{ MLA $\left(\mathrm{mg} \mathrm{L}^{-1}\right)$ in rivers } \\
\hline & & \multicolumn{2}{|c|}{ Agricultural irrigation (A) } & \multicolumn{2}{|c|}{ Public-urban (B) } & \multicolumn{2}{|c|}{ Protection of aquatic life $(\mathrm{C})$} \\
\hline & & p.d & p.m & p.d & p.m & p.d & p.m \\
\hline $\mathrm{Al}$ & 15.46 & - & - & - & - & - & - \\
\hline As & $<0.098$ & 0.2 & 0.4 & 0.1 & 0.2 & 0.1 & 0.2 \\
\hline $\mathrm{Cd}$ & $<0.114$ & 0.2 & 0.4 & 0.1 & 0.2 & 0.1 & 0.2 \\
\hline Co & 2.42 & - & - & - & - & - & - \\
\hline $\mathrm{Cu}^{*}$ & 6.89 & 4.0 & 6.0 & 4.0 & 6.0 & 4.0 & 6.0 \\
\hline $\mathrm{Cr}^{*}$ & 1.95 & 1.0 & 1.5 & 0.5 & 1.0 & 0.5 & 1.0 \\
\hline $\mathrm{Fe}$ & 1,323 & - & - & - & - & - & - \\
\hline $\mathrm{Mn}$ & 7.23 & - & - & - & - & - & - \\
\hline $\mathrm{Ca}$ & 148.87 & - & - & - & - & - & - \\
\hline $\mathrm{Mg}$ & 34 & - & - & - & - & - & - \\
\hline $\mathrm{Na}$ & 19,148 & - & - & - & - & - & - \\
\hline $\mathrm{Hg}^{*}$ & 0.07 & 0.01 & 0.02 & 0.005 & 0.01 & 0.005 & 0.01 \\
\hline $\mathrm{Ni}^{*}$ & 6.75 & 2 & 4 & 2 & 4 & 2 & 4 \\
\hline $\mathrm{Pb}^{*}$ & 1.23 & 0.5 & 1 & 0.2 & 0.4 & 0.2 & 0.4 \\
\hline $\mathrm{Zn}$ & 4.68 & 10 & 20 & 10 & 10 & 20 & 10 \\
\hline $\mathrm{V}$ & 0.24 & - & - & - & - & - & - \\
\hline
\end{tabular}

MLA = maximum limits allowed; $\mathrm{p} \cdot \mathrm{d}=$ per day; $\mathrm{p} \cdot \mathrm{m}=$ per month.

${ }^{*}$ Values that exceed the established MLA under Mexican Regulation.<smiles>Cc1ccc(O)c(C)c1</smiles>

(a)

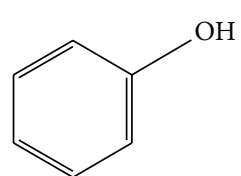

(b)<smiles>Cc1cccc(O)c1</smiles>

(c)<smiles>Cc1ccc(O)cc1</smiles>

(d)<smiles>Cc1ccccc1O</smiles>

(e)

FIGURE 3: Chemical structure of the main phenolic compounds identified by GC-MS in the spent caustics mixture: (a) 2,4-dimethylphenol, (b) phenol, (c) m-methylphenol, (d) p-methylphenol, and (e) o-methylphenol.

This analysis showed a uniform distribution of $\operatorname{Ir}\left(a_{1}\right)$, $\mathrm{Ta}\left(\mathrm{a}_{2}\right), \mathrm{Sn}\left(\mathrm{b}_{1}\right), \mathrm{B}\left(\mathrm{c}_{1}\right)$, and $\mathrm{C}\left(\mathrm{c}_{2}\right)$. However, the $\mathrm{Sb}$, in the case of $\mathrm{Ti} / \mathrm{SnO}_{2}-\mathrm{Sb}$, was not detected. The absence of $\mathrm{Sb}$ was probably due to the additive ratio in the coating solution. To verify its presence, an $\mathrm{XRD}$ analysis was done demonstrating the presence of $\mathrm{SnO}_{2}, \mathrm{Sb}_{2} \mathrm{O}_{3}$, and $\mathrm{Sb}_{2} \mathrm{O}_{5}$. For this specific reason, pretreatment of this electrode was performed before the cyclic voltammetric analysis. At the same time, for both materials ( $\mathrm{Ti} / \mathrm{IrO}_{2}-\mathrm{Ta}_{2} \mathrm{O}_{5}$ and $\left.\mathrm{Ti} / \mathrm{SnO}_{2}-\mathrm{Sb}\right)$, the $\mathrm{wt} \%$ of each element was obtained by EDS. In this analysis, the presence of additional elements such as $\mathrm{O}, \mathrm{Ti}$, and $\mathrm{Si}$ was detected. The results of these analyses (XRD and EDS) have been omitted due to the formulation used. In the case of Ti/BDD, an exhaustive characterization was performed in other studies [94]. The electrochemical characterization of each electrode by $\mathrm{CV}$ is shown in Figure 4(d). It shows a comparative analysis of $\mathrm{Ti} / \mathrm{IrO}_{2}-\mathrm{Ta}_{2} \mathrm{O}_{5}\left(\mathrm{~d}_{1}\right), \mathrm{Ti} / \mathrm{SnO}_{2}-\mathrm{Sb}\left(\mathrm{d}_{2}\right)$, and Ti/BDD $\left(\mathrm{d}_{3}\right)$, in $0.5 \mathrm{M} \mathrm{H}_{2} \mathrm{SO}_{4}$. This graph shows that $\mathrm{Ti} / \mathrm{BDD}$ has the highest potential window in comparison to $\mathrm{Ti} / \mathrm{IrO}_{2}-\mathrm{Ta}_{2} \mathrm{O}_{5}$ and $\mathrm{Ti} / \mathrm{SnO}_{2}-\mathrm{Sb}$. An elevated $\eta \mathrm{O}_{2}$ is important taking into account that the oxidation reaction of the organic compounds during the EO occurs in parallel to the evolution of $\mathrm{O}_{2}$. Using a material with a high $\eta \mathrm{O}_{2}$, the oxidation reaction is favored over the evolution of $\mathrm{O}_{2}$, resulting in high current efficiencies. Based on this, it was decided that Ti/BDD was the best material to use in the electrochemical treatment of spent caustic.

3.2.2. Selection of the Reaction Medium. To carry out the electrochemical destruction of the spent caustics using $\mathrm{Ti} / \mathrm{BDD}$, the selection of the reaction medium was done taking into account the following approaches: (i) the $\mathrm{pH}$ effect on the chemical state of phenol, (ii) the $\mathrm{pH}$ effect on the $\mathrm{Ti} / \mathrm{BDD}$ 's electrochemical response, and (iii) the $\mathrm{pH}$ effect 


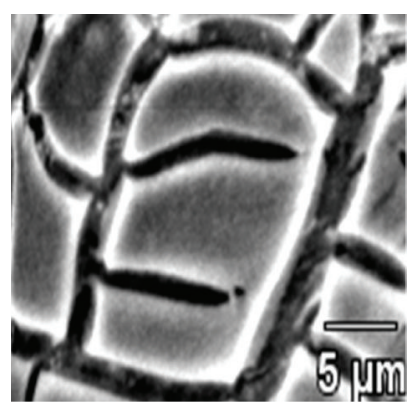

(a)

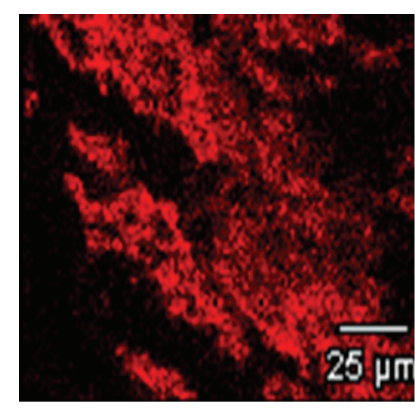

$\left(a_{1}\right)$

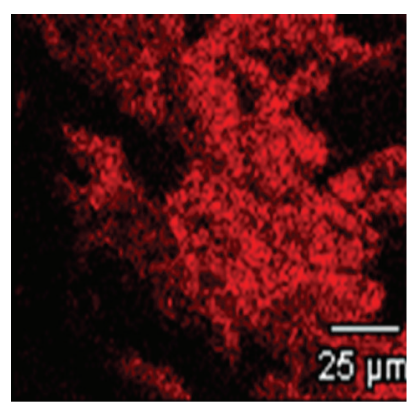

$\left(\mathrm{a}_{2}\right)$

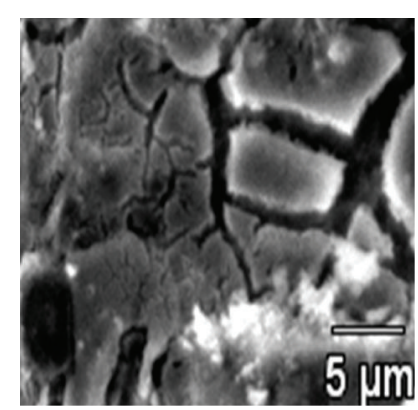

(b)

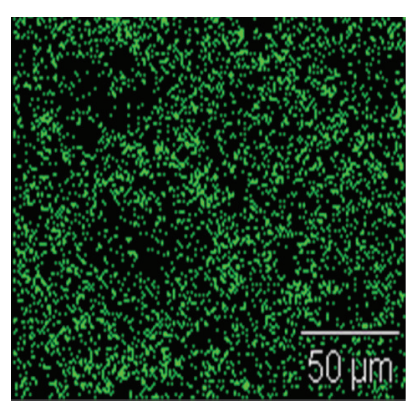

$\left(b_{1}\right)$

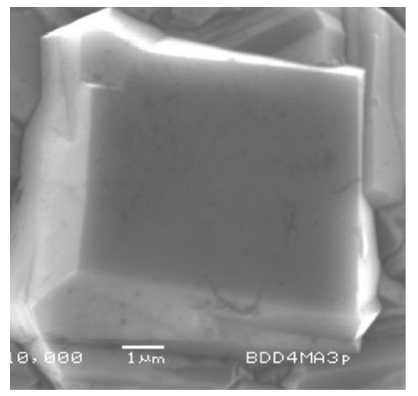

(c)

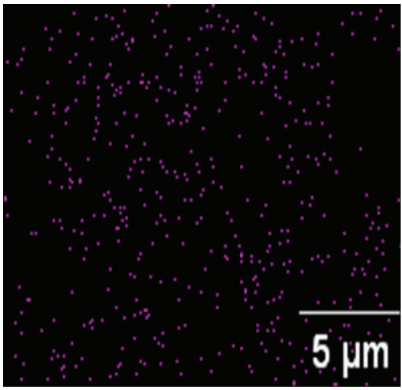

$\left(c_{1}\right)$

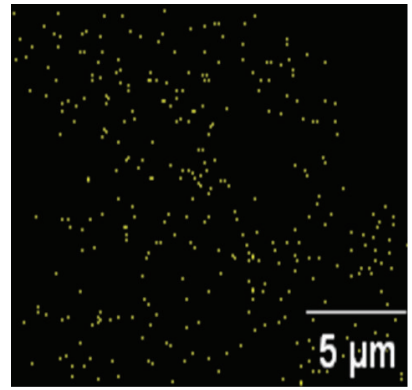

$\left(c_{2}\right)$

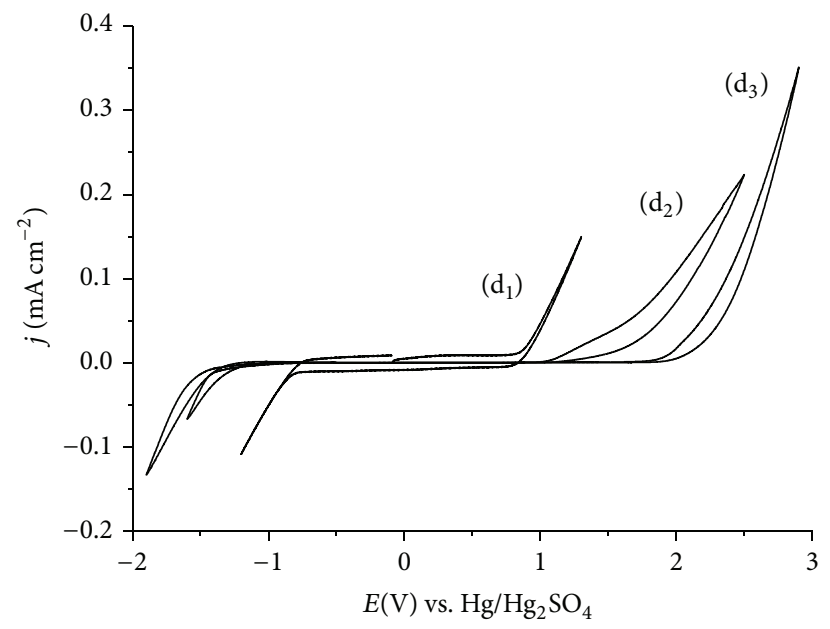

(d)

Figure 4: SEM analysis. (a) $\mathrm{Ti} / \mathrm{IrO}_{2}-\mathrm{Ta}_{2} \mathrm{O}_{5}$. (b) $\mathrm{Ti} / \mathrm{SnO}_{2}$ - Sb. (c) Ti/BDD, applying $15 \mathrm{kV}$ with its respective micrographies and X-ray dotmapping analysis, identifying: $\left(\mathrm{a}_{1}\right) \mathrm{Ir},\left(\mathrm{a}_{2}\right) \mathrm{Ta},\left(\mathrm{b}_{1}\right) \mathrm{Sn},\left(\mathrm{c}_{1}\right) \mathrm{B}$, and $\left(\mathrm{c}_{2}\right) \mathrm{C}$. (d) Cyclic voltammetry analysis for $\left(\mathrm{d}_{1}\right) \mathrm{Ti} / \mathrm{IrO}_{2}-\mathrm{Ta}_{2} \mathrm{O}_{5},\left(\mathrm{~d}_{2}\right) \mathrm{Ti} / \mathrm{SnO} \mathrm{O}_{2}-$ $\mathrm{Sb}$, and $\left(\mathrm{d}_{3}\right) \mathrm{Ti} / \mathrm{BDD}$ in $0.5 \mathrm{M} \mathrm{H}_{2} \mathrm{SO}_{4}$. 


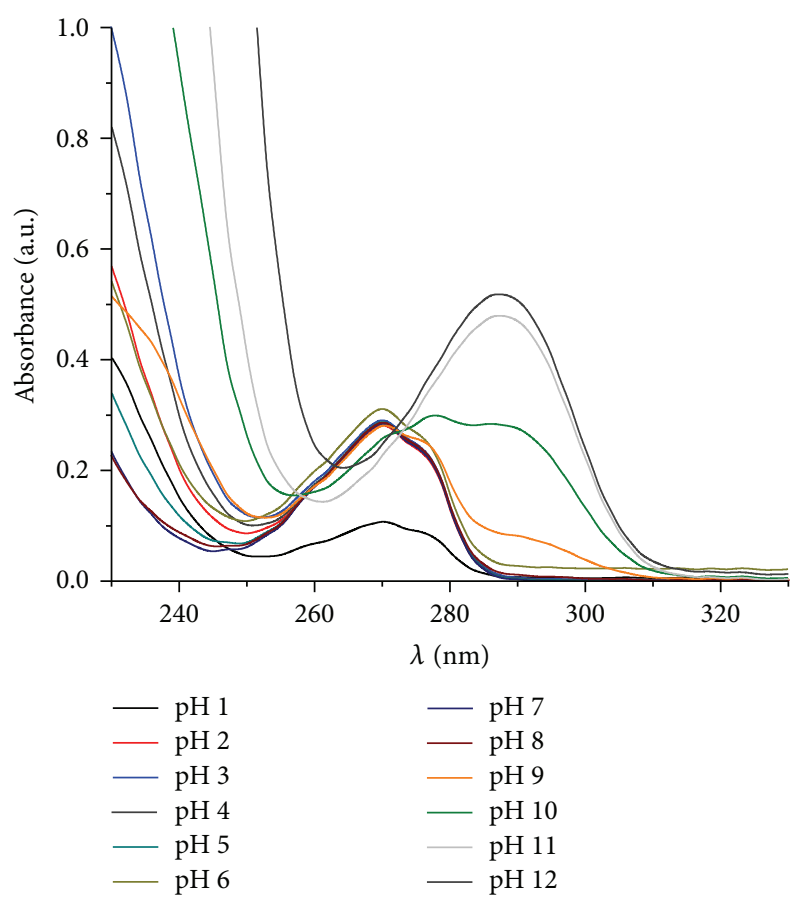

(a)

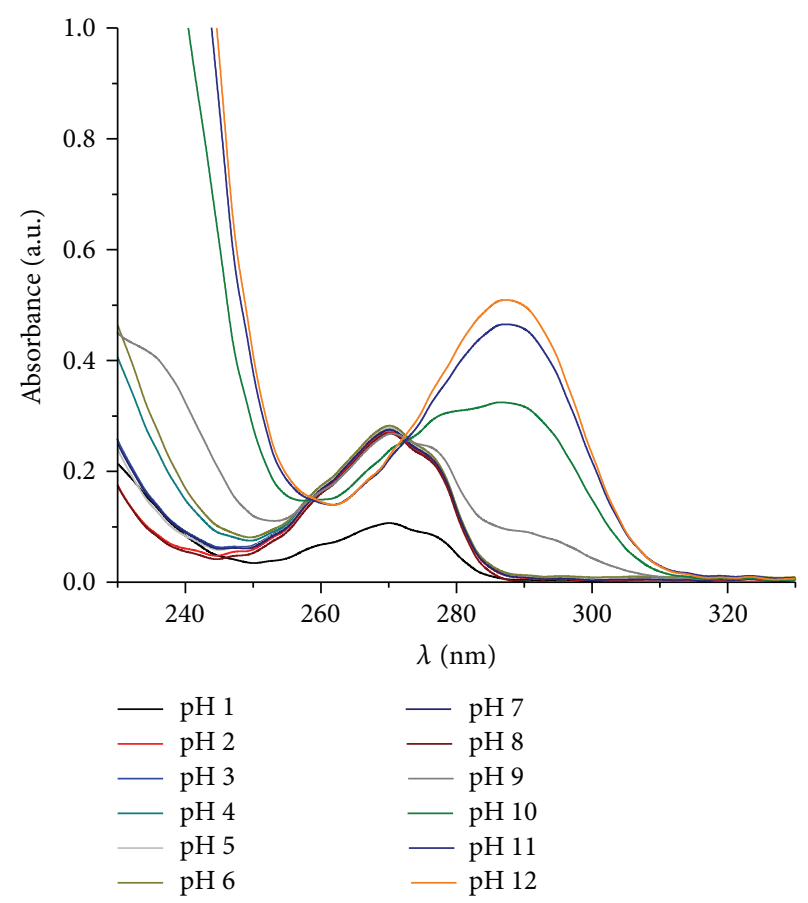

(b)

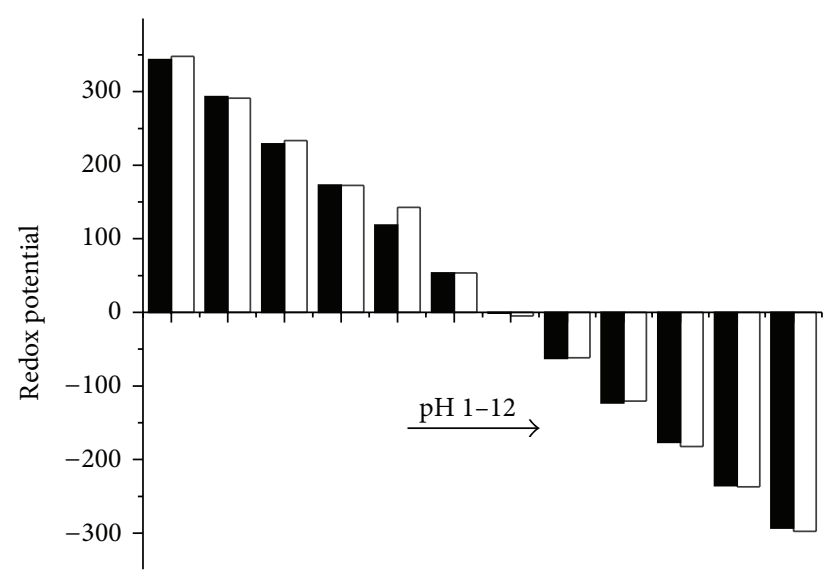

(c)

Figure 5: UV-Vis analysis of the $\mathrm{pH}$ effect on the chemical state of phenol, using $30 \mathrm{mg} \mathrm{L}^{-1}$ of TOC in (a) $0.05 \mathrm{M} \mathrm{NaOH} / \mathrm{H}_{2} \mathrm{SO}_{4}\left(\mathrm{pH}_{12}-1\right)$, (b) $0.05 \mathrm{M} \mathrm{NaOH} / \mathrm{HCl}$ (pH 12-1), and (c) ORP analysis under the same conditions to $298 \mathrm{~K}$.

on ${ }^{\circ}$ OHs production. According to the first approach, in an extremely alkaline environment $(\mathrm{pH} 13-13.5$, Table 1), the phenol is chemically transformed into sodium phenolates [90]. Although the electronic state of phenol in an alkaline medium has been shown to be favorable for an EO process using electrodes with a low $\eta \mathrm{O}_{2}$ [28], this does not occur using $\mathrm{BDD}$, where the most degradation efficiency is obtained using an acidic medium [90]. Frequently, in literature, different types of acids have been reported for the $\mathrm{EO}$ of phenol, such as $\mathrm{HClO}_{4}[63,104]$ and $\mathrm{HNO}_{3}[105]$; however, for a possible industrial application, the costs of said acids must be considered. For this reason and considering that during the ion analysis a high quantity of chlorides $\left(54,900 \mathrm{mg} \mathrm{L}^{-1}\right)$ and sulfates $\left(1,882 \mathrm{mg} \mathrm{L}^{-1}\right)$ was identified as part of the chemical composition of the spent caustics mixture, $\mathrm{HCl}$ and $\mathrm{H}_{2} \mathrm{SO}_{4}$ were selected as possible acids to carry out the $\mathrm{pH}$ adjustment $(13,13.5$ to 1$)$. Initially, the acidification process was evaluated using a synthetic sample in order to rule out any chemical change that occurred on the phenol molecule during the acidification process and to avoid an overestimation of the subsequent results. In said analysis, a solution of $0.05 \mathrm{M} \mathrm{NaOH}$ containing phenol $30 \mathrm{mg} \mathrm{L}^{-1}$ (TOC) was adjusted to different $\mathrm{pH}$ values in an interval of $12-1$, using $0.5 \mathrm{M} \mathrm{HCl}$ and $\mathrm{H}_{2} \mathrm{SO}_{4}$. The changes that occurred during the acidification process were evaluated through UV-Vis spectroscopy. Figure 5 shows the different UV-Vis absorption spectrums obtained during the adjustment of the $\mathrm{pH}$ using $\mathrm{H}_{2} \mathrm{SO}_{4}$ (Figure 5(a)) and $\mathrm{HCl}$ (Figure 5(b)). It is clearly observed that the chemical 


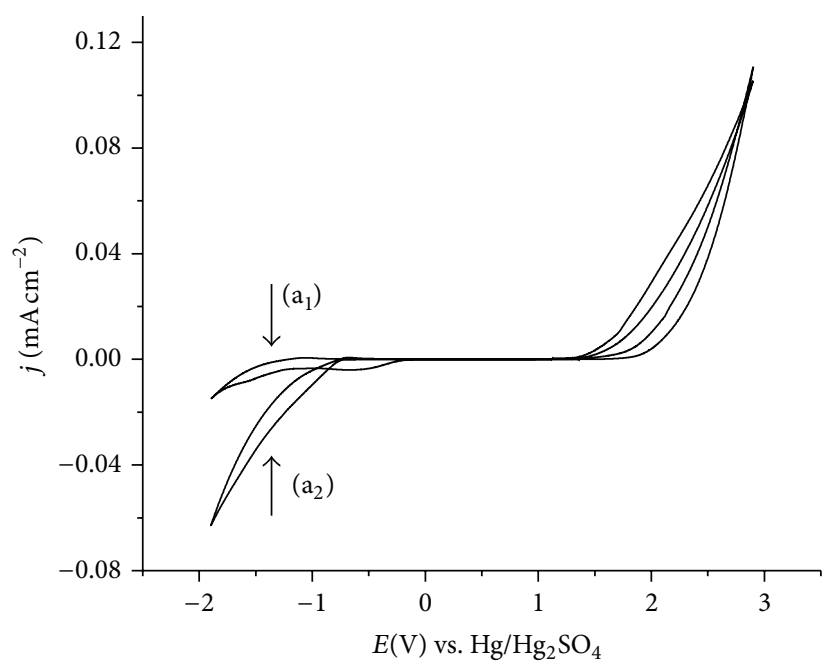

(a)

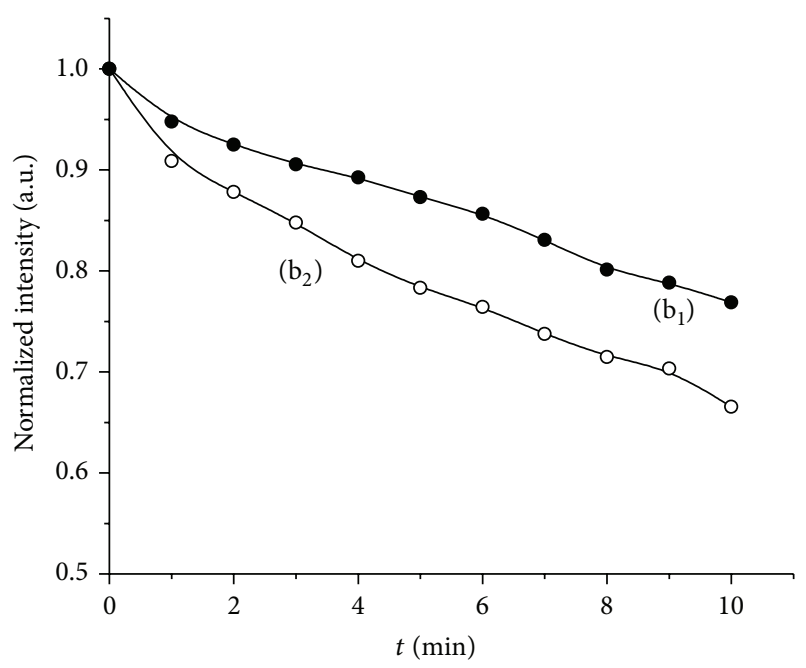

(b)

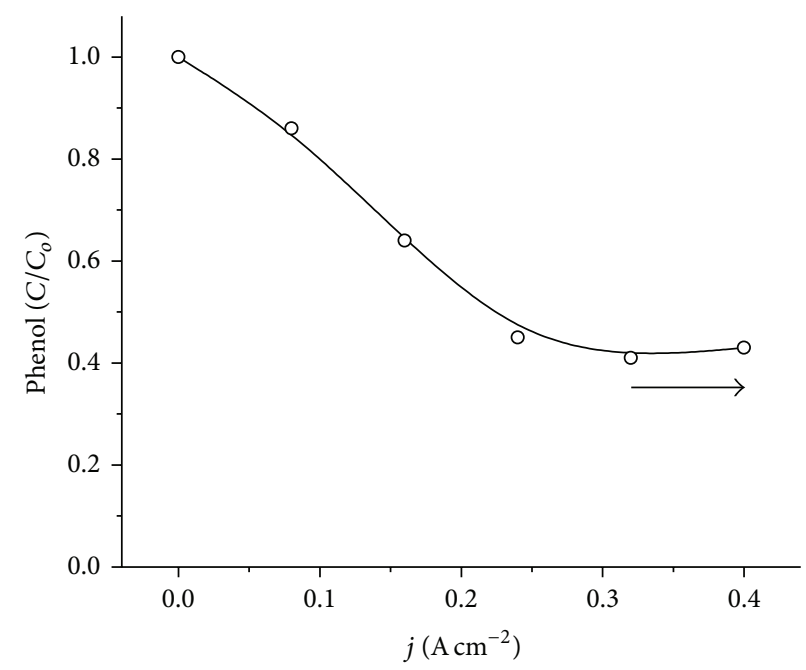

(c)

Figure 6: Electrochemical characterization of Ti/BDD by cyclic voltammetric analysis using $\left(\mathrm{a}_{1}\right) 0.05 \mathrm{M} \mathrm{NaOH} / \mathrm{HCl}(\mathrm{pH} 1)$ and $\left(\mathrm{a}_{2}\right) 0.05 \mathrm{M}$ $\mathrm{NaOH} / \mathrm{H}_{2} \mathrm{SO}_{4}$ (pH 1). (b) ${ }^{\circ} \mathrm{OHs}$ analysis by fluorescence spectroscopy using $\left(\mathrm{b}_{1}\right) 0.05 \mathrm{M} \mathrm{NaOH} / \mathrm{HCl}(\mathrm{pH} 1)$ and $\left(\mathrm{b}_{2}\right) 0.05 \mathrm{M} \mathrm{NaOH} / \mathrm{H}_{2} \mathrm{SO}_{4}$ $\left(\mathrm{pH}\right.$ ). (c) Selection of the current density using synthetic solutions of phenol (30 mg L ${ }^{-1}$ of TOC) in $0.05 \mathrm{NaOH} / \mathrm{H}_{2} \mathrm{SO}_{4}(\mathrm{pH} 1)$.

conversion of sodium phenolates to phenol $(\lambda=270 \mathrm{~nm})$ is obtained with both types of acids at a $\mathrm{pH}$ of 9 , reaching the maximum conversion efficiency at a $\mathrm{pH}$ of 7 .

There were no additional and significant chemical changes observed. In parallel to this measurement, an analysis of the redox potential (ORP) was carried out at $298 \mathrm{~K}$. The result of this analysis is shown in Figure 5(c). The values obtained clearly show that an acidic $\mathrm{pH}$ favors highly oxidizing conditions, which is of high importance considering that, albeit, an acidic environment does not alter the chemical structure of phenol, the contaminants associated with the spent caustics can be liberated, whereby, a specialized infrastructure and safety equipment are necessary. Using $\mathrm{H}_{2} \mathrm{SO}_{4}$, a slight increase in the ORP was observed in comparison with $\mathrm{HCl}$, which is logical considering a greater number of protons. To evaluate the second approach (effect of the $\mathrm{pH}$ on the electrochemical response of the $\mathrm{Ti} / \mathrm{BDD})$, different voltammograms were obtained through the adjustment of $0.05 \mathrm{M} \mathrm{NaOH}$ with $0.5 \mathrm{H}_{2} \mathrm{SO}_{4}$ and $\mathrm{HCl}$ in a $\mathrm{pH}$ range of $12-1$ (data not shown). It was observed that when the $\mathrm{pH}$ values descended to acidic, the $\eta \mathrm{O}_{2}$ increased considerably [106]. When comparing the window of potential of $\mathrm{H}_{2} \mathrm{SO}_{4}$ with that of $\mathrm{HCl}(\mathrm{pH} \mathrm{1})$ (Figure 6(a)), a difference in overpotential of $0.5 \mathrm{~V}$ was obtained. Considering these results and according to the third approach ( $\mathrm{pH}$ effect on ${ }^{\circ} \mathrm{OHs}$ production), an analysis of the generation of the ${ }^{\bullet} \mathrm{OH}$ s was carried out in both reaction mediums ( $\mathrm{pH} 1$ ). Figure $6(\mathrm{~b})$ shows the influence of the reaction medium on the production of ${ }^{\circ} \mathrm{OHs}$. It is clearly observed that the production of ${ }^{\circ} \mathrm{OH}$ s is greater in $\mathrm{NaOH}$ / $\mathrm{H}_{2} \mathrm{SO}_{4}$ (pH 1).

This result is of great importance considering that, with the use of a BDD electrode, the formation of any oxidizing species produced in parallel to the oxidation of organic compounds is strictly dependent on the formation of 


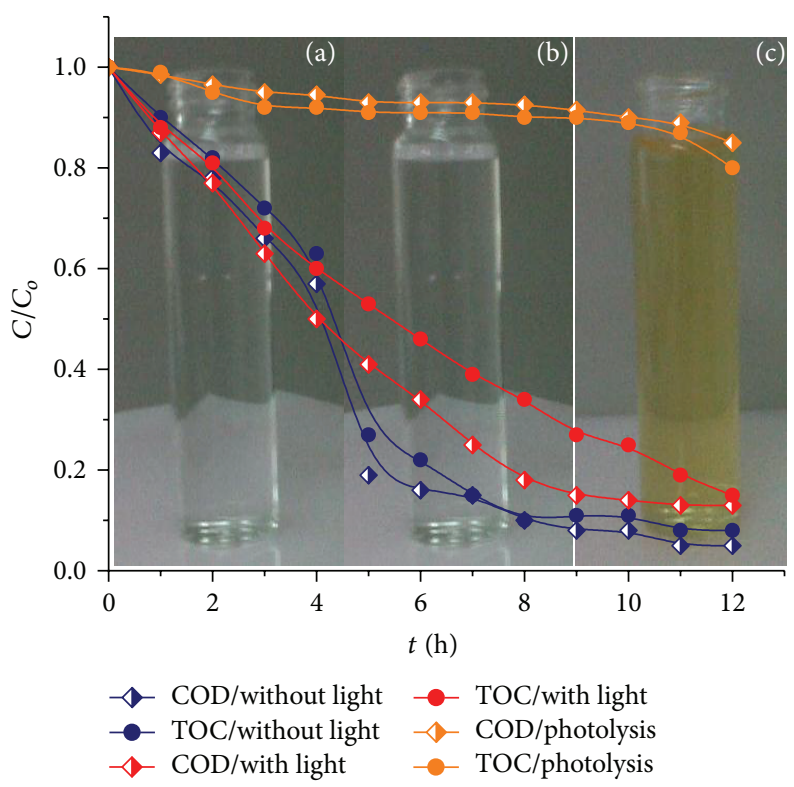

FIGURE 7: Evaluation of the use of UV light $(\lambda=254 \mathrm{~nm})$. Removal of COD and TOC in spent caustic corresponding to the simple sample using Ti/BDD, applying $0.96 \mathrm{~A}\left(j=0.32 \mathrm{~A} \mathrm{~cm}^{-2}\right)$, under constant stirring, $\mathrm{pH} 1$ (adjustment with $\left.\mathrm{H}_{2} \mathrm{SO}_{4}\right)$ and $t_{r}=12 \mathrm{~h}$. Images of $(\mathrm{a})$ in the absence of UV light, (b) in the presence of UV light $(\lambda=254 \mathrm{~nm})$, and (c) photolysis.

the ${ }^{\bullet} \mathrm{OHs}$. Based on this result, $\mathrm{H}_{2} \mathrm{SO}_{4}$ was selected to carry out the acidification process.

3.2.3. Electrolysis Using Ti/BDD. Before performing the degradation experiments, a preliminary analysis using a synthetic solution with a phenol concentration of $30 \mathrm{mg} \mathrm{L}^{-1}$ of TOC was carried out in $\mathrm{NaOH} / \mathrm{H}_{2} \mathrm{SO}_{4}(\mathrm{pH} 1)$ with the goal of identifying the current to be applied. The currents evaluated were $0.24,0.48,0.72,0.96,1.20$, and $1.44 \mathrm{~A}$, for a 2-hour period, under constant stirring. Ti/BDD $\left(3 \mathrm{~cm}^{2}\right)$ was used as anode and $\mathrm{Ti} / \mathrm{Pt}\left(3 \mathrm{~cm}^{2}\right)$ was used as counterelectrode. It was observed that the middle point of the removal was reached at $0.96 \mathrm{~A}\left(j=0.32 \mathrm{~A} \mathrm{~cm}^{-2}\right)$, as shown in Figure 6(c). After having identified the current to be applied and before carrying out electrolysis of the spent caustics mixture, a preliminary electrolysis was performed using a simple sample (Table 1). The conditions of electrolysis were $j=0.32 \mathrm{~A} \mathrm{~cm}^{-2}, \mathrm{pH} 1$ (adjustment with $\mathrm{H}_{2} \mathrm{SO}_{4}$ ). In this analysis, the effect of ultraviolet light was considered for the purpose of favoring the synergic effect on the production of the ${ }^{\circ} \mathrm{OH}$. It has been reported that, in the presence of chlorides, the use of ultraviolet light $(\lambda=254 \mathrm{~nm})$ can lead to the production of the ${ }^{\circ} \mathrm{OH}$, according to the reaction (4):

$$
\mathrm{HOCl}+h v \longrightarrow{ }^{\bullet} \mathrm{OH}+{ }^{\bullet} \mathrm{Cl}
$$

Figure 7 shows the degradation profiles (TOC and COD) obtained in the different analyses done in the presence and absence of UV light $(\lambda=254 \mathrm{~nm})$.

The results obtained in electrolysis in the absence of light were more satisfactory than those obtained in its presence $(\lambda=254 \mathrm{~nm})$. The results obtained can be attributed to the type of sample analyzed. A real sample is not comparable to a synthetic sample. Here, it is inferred that, due to the high content of organic material, oxidation processes, different from those that occurred in the interface or by the action of the oxidants themselves, are not significant. When analyzing the effect of UV light $(\lambda=254 \mathrm{~nm})$, without applying a current (photolysis), no significant change was observed.

Figure 8 shows the analysis of images obtained during the different electrolysis carried out.

The initial image $\left(t_{r}=0 \mathrm{~h}\right)$ corresponds to the simple sample submitted to a special pretreatment before electrolysis (acidification to $\mathrm{pH} 1$ using $\mathrm{H}_{2} \mathrm{SO}_{4}$ ). A dark brown color in the first stages of the phenol electrolysis is related to the formation of byproducts such as benzoquinone and hydroquinone, known as an active redox couple in equilibrium in an aqueous solution [51]. The color degradation in each experiment was gradual. When comparing each image $\left(t_{r}=8 \mathrm{~h}\right)$, it is clearly observed that, in electrolysis carried out in the absence of light (Figure 8(a)), the sample turned completely crystalline, indicating a high level of destruction of the organic content. Contrarily, in electrolysis in the presence of light $(\lambda=254 \mathrm{~nm}$ ) (Figure $8(\mathrm{~b})$ ) and in photolysis experiments (Figure $8(\mathrm{c})$ ), the opposite process was observed. In the presence of light $(\lambda=254 \mathrm{~nm})$, the degradation time to obtain a visually crystalline sample was greater $\left(t_{r}=12 \mathrm{~h}\right)$. Based on these results, the use of UV light $(\lambda=254 \mathrm{~nm})$ was discarded. On the other hand and considering the results obtained, the possible passivation of $\mathrm{Ti} / \mathrm{BDD}$ as an important point was also evaluated. In this analysis, the ${ }^{\circ} \mathrm{OHs}$ production was performed in function of the interfacial potential or current applied. The result (data not shown) indicates that these species only are generated in the zone corresponding to the decomposition of the medium, whereby, if the domains of the potential or current applied are not the correct ones, the electrode can be completely 

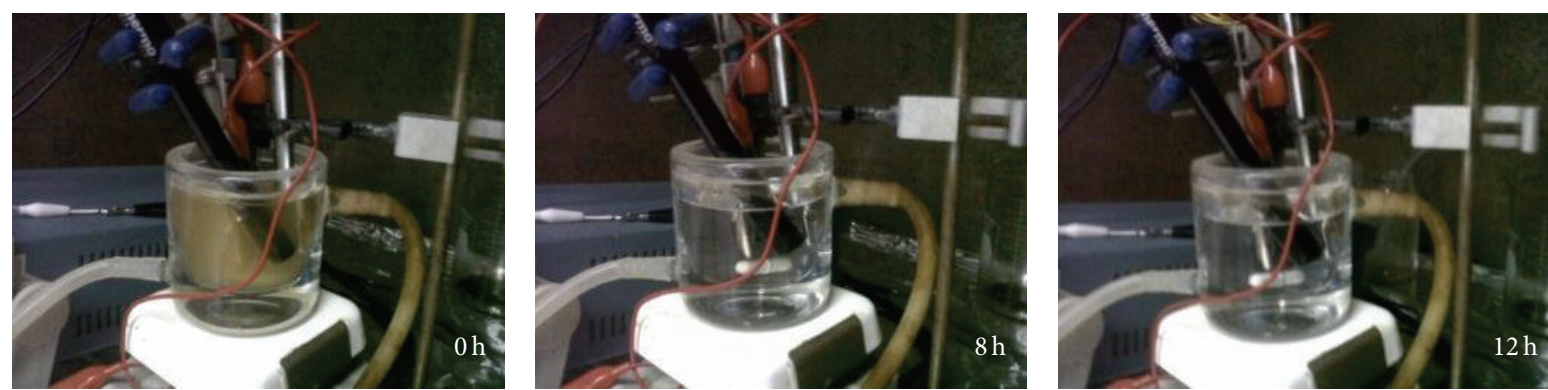

(a)
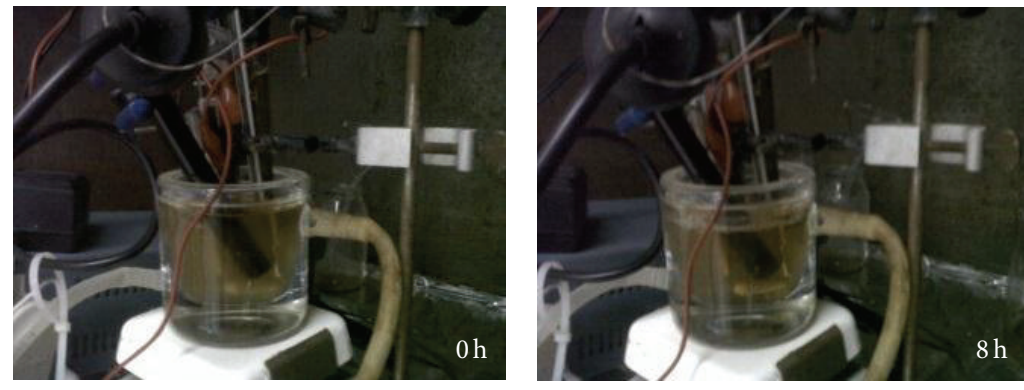

(b)
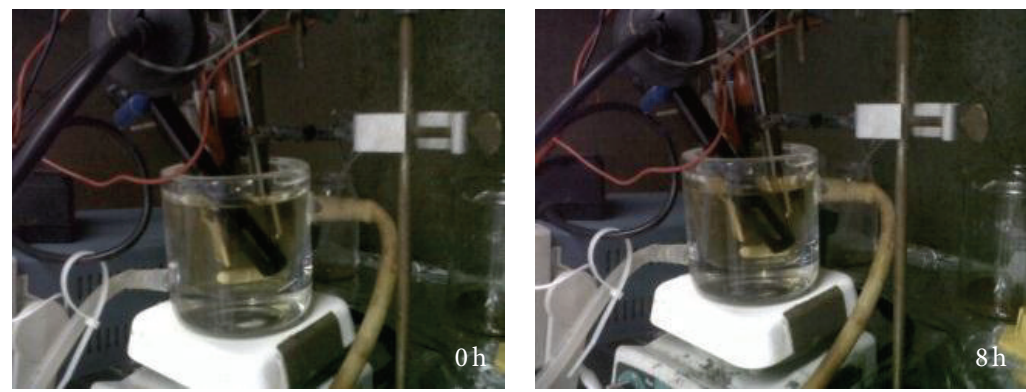

(c)
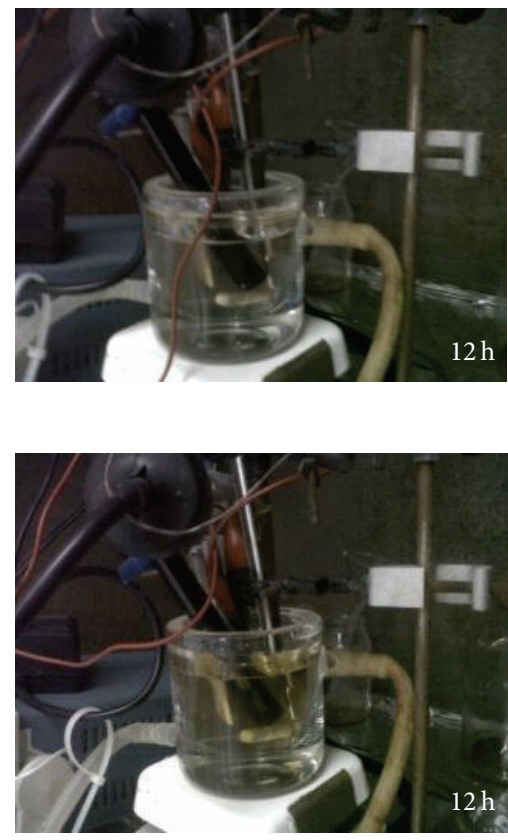

FIGURE 8: Images of electrolysis of spent caustic corresponding to the simple sample. (a) In the absence of UV light. (b) In the presence of UV light $(\lambda=254 \mathrm{~nm})$. (c) Photolysis, using Ti/BDD, applying $0.96 \mathrm{~A}\left(j=0.32 \mathrm{~A} \mathrm{~cm}^{-2}\right)$, under constant stirring, $\mathrm{pH}_{1}\left(\right.$ adjustment with $\left.\mathrm{H}_{2} \mathrm{SO}_{4}\right)$ and $t_{r}=12 \mathrm{~h}$.

TABLE 3: Electrochemical treatment of spent caustics (mixture) using Ti/BDD.

\begin{tabular}{lcccccc}
\hline Sample & $\begin{array}{c}\text { COD } \\
\left(\mathrm{mg} \mathrm{L}^{-1}\right)\end{array}$ & $\begin{array}{c}\text { COD removal } \\
(\%)\end{array}$ & $\begin{array}{c}\text { Total removal } \\
\text { efficiency, WT-ET }(\%)\end{array}$ & $\begin{array}{c}\text { TOC } \\
\left(\mathrm{mg} \mathrm{L}^{-1}\right)\end{array}$ & $\begin{array}{c}\text { TOC removal } \\
(\%)\end{array}$ & $\begin{array}{c}\text { Total removal } \\
\text { efficiency, WT-ET }(\%)\end{array}$ \\
\hline Without treatment (WT) & 98,750 & 0 & - & $20,137.5$ & 0 & 0 \\
Chemical treatment (CT) & 24,533 & 75.15 & - & 15,700 & 22.03 & - \\
Electrochemical treatment (ET) & 2,333 & 90.40 & 96.63 & 2,322 & 85.21 & 88.46 \\
\hline
\end{tabular}

${ }^{*}$ Acidification to $\mathrm{pH} 1$ using $\mathrm{H}_{2} \mathrm{SO}_{4}$.

passivated. The image analysis of this test is shown in Figure 9. As can be observed (Figure 9(a)), when working with a current, where the production of the ${ }^{\circ} \mathrm{OHs}$ does not occur, a thick layer of organic compounds is deposited, causing the deactivation of the electrode.

Contrarily, when the current is applied, inducing a greater interfacial potential by which ${ }^{\circ} \mathrm{OH}$ are electrogenerated, the Ti/BDD electrode can be operated successfully (Figure 9(b)). Finally and according to the previous studies, the electrolysis of the mixture $(100 \mathrm{~mL})$ of spent caustics was carried out
( $\mathrm{pH} 1 / \mathrm{H}_{2} \mathrm{SO}_{4}, j=0.32 \mathrm{~A} \mathrm{~cm}^{-2}$ ). The results obtained in this analysis are shown in Table 3 . The results obtained were similar to those from electrolysis of the simple sample.

The analysis of the image of the sample corresponding to the mixture of spent caustics before and after the electrochemical treatment with $\mathrm{Ti} / \mathrm{BDD}\left(t_{r}=15 \mathrm{~h}\right)$ is shown in Figures 9(c) and 9(d), respectively. Complementary analyses of toxicity and phenol in all of its forms showed that the sample electrochemically treated is not toxic, presenting a low phenol content $(<3 \mathrm{ppm})$, with this value being 


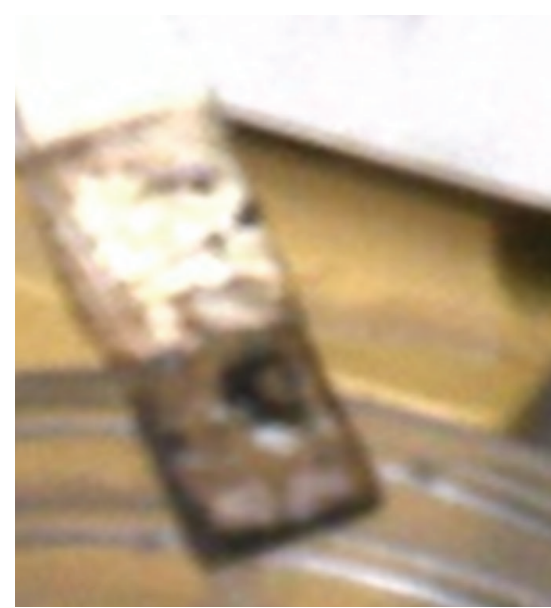

(a)

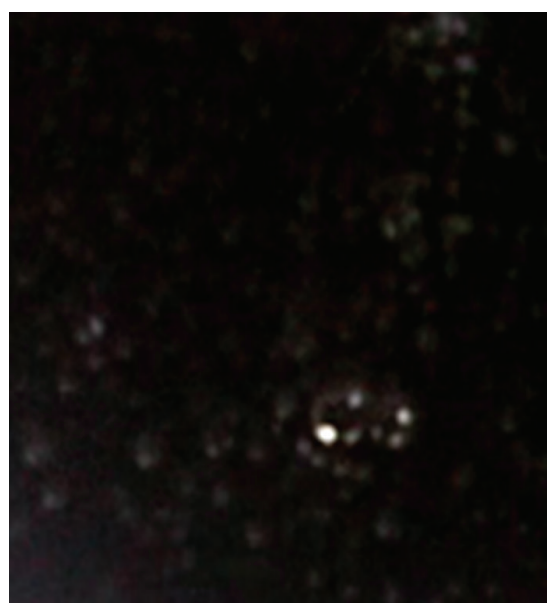

(c)

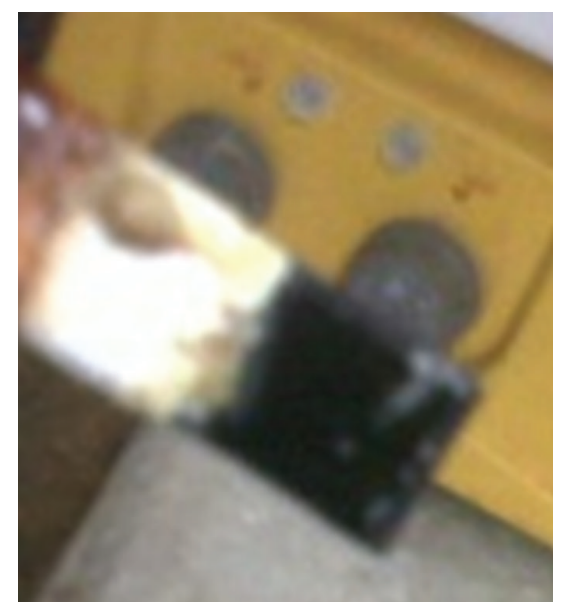

(b)

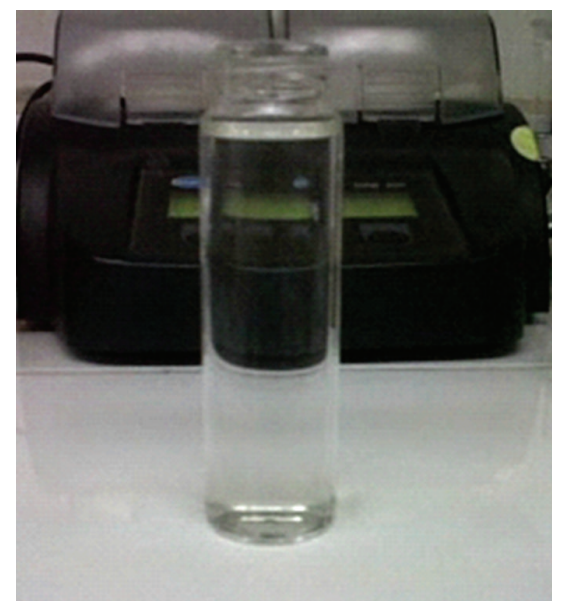

(d)

Figure 9: Electrochemical treatment of spent caustics mixture. (a) Applying a current where the ${ }^{\circ}$ OHs are not generated. (b) Applying a current where the ${ }^{\circ} \mathrm{OHs}$ are generated. (c) Electrolyzed sample (without pretreatment). (d) Sample obtained after the electrochemical treatment with Ti/BDD applying $0.96 \mathrm{~A}\left(j=0.32 \mathrm{~A} \mathrm{~cm}^{-2}\right)$, under constant stirring, $\mathrm{pH} 1$ (adjustment with $\left.\mathrm{H}_{2} \mathrm{SO}_{4}\right)$ and $t_{r}=15 \mathrm{~h}$.

the minimum standard discharge limit for refinery effluents [107].

\section{Conclusions}

A greater production of the ${ }^{\bullet} \mathrm{OH}$ was obtained by using $\mathrm{H}_{2} \mathrm{SO}_{4}$ as a reaction medium. The degradation of spent caustics in an acidic medium $\left(\mathrm{H}_{2} \mathrm{SO}_{4}, \mathrm{pH} 1\right)$ using Ti/BDD in simple samples proceeded at $100 \%$, while for the mixture, percentages of destruction of $90.40 \%$ and $85.21 \%$ for COD and TOC, respectively, were obtained. The use of UV light $(\lambda=$ $254 \mathrm{~nm}$ ) did not show an improvement of the process. Further studies are necessary to improve the efficiencies obtained.

\section{Conflict of Interests}

The authors declare that there is no conflict of interests regarding the publication of this paper.

\section{Acknowledgments}

The authors would like to thank Mexico's National Council of Science and Technology (CONACyT) for its financial support of this research. The authors also thank Ms. Alejandra Rojo (native speaker) for her review of this paper.

\section{References}

[1] I. Hariz, A. Halleb, N. Adhoum, and L. Monser, "Treatment of petroleum refinery sulfidic spent caustic wastes by electrocoagulation," Separation and Purification Technology, vol. 107, pp. 150-157, 2013.

[2] S.-H. Sheu and H.-S. Weng, "Treatment of olefin plant spent caustic by combination of neutralization and fenton reaction," Water Research, vol. 35, no. 8, pp. 2017-2021, 2001.

[3] A. Olmos, P. Olguin, C. Fajardo, E. Razo, and O. Monroy, "Physicochemical characterization of spent caustic from the 
OXIMER process and sour waters from mexican oil refineries," Energy \& Fuels, vol. 18, no. 2, pp. 302-304, 2004.

[4] H. Jiang, Y. Fang, Y. Fu, and Q.-X. Guo, "Studies on the extraction of phenol in wastewater," Journal of Hazardous Materials, vol. 101, no. 2, pp. 179-190, 2003.

[5] Y. Han, X. Quan, S. Chen, H. Zhao, C. Cui, and Y. Zhao, "Electrochemically enhanced adsorption of phenol on activated carbon fibers in basic aqueous solution," Journal of Colloid and Interface Science, vol. 299, no. 2, pp. 766-771, 2006.

[6] A. Nuhoglu and B. Yalcin, "Modelling of phenol removal in a batch reactor," Process Biochemistry, vol. 40, no. 3-4, pp. 12331239, 2005.

[7] D. Rajkumar and K. Palanivelu, "Electrochemical treatment of industrial wastewater," Journal of Hazardous Materials, vol. 113, no. 1-3, pp. 123-129, 2004.

[8] H. Polat, M. Molva, and M. Polat, "Capacity and mechanism of phenol adsorption on lignite," International Journal of Mineral Processing, vol. 79, no. 4, pp. 264-273, 2006.

[9] Y. Yavuz, A. S. Koparal, and Ü. B. Ögütveren, "Treatment of petroleum refinery wastewater by electrochemical methods," Desalination, vol. 258, no. 1-3, pp. 201-205, 2010.

[10] H. Farajnezhad and P. Gharbani, "Coagulation treatment of wastewater in petroleum industry using poly aluminum chloride and ferric chloride," International Journal of Research and Reviews in Applied Sciences, vol. 13, no. 1, pp. 306-310, 2012.

[11] L. Altaş and H. Büyükgüngör, "Sulfide removal in petroleum refinery wastewater by chemical precipitation," Journal of Hazardous Materials, vol. 153, no. 1-2, pp. 462-469, 2008.

[12] C. E. Santo, V. J. P. Vilar, C. M. S. Botelho, A. Bhatnagar, E. Kumar, and R. A. R. Boaventura, "Optimization of coagulationflocculation and flotation parameters for the treatment of a petroleum refinery effluent from a Portuguese plant," Chemical Engineering Journal, vol. 183, pp. 117-123, 2012.

[13] M. H. El-Naas, S. Al-Zuhair, A. Al-Lobaney, and S. Makhlouf, "Assessment of electrocoagulation for the treatment of petroleum refinery wastewater," Journal of Environmental Management, vol. 91, no. 1, pp. 180-185, 2009.

[14] C.-L. Yang, "Electrochemical coagulation for oily water demulsification," Separation and Purification Technology, vol. 54, no. 3, pp. 388-395, 2007.

[15] M. A. Zazouli, M. Taghavi, and E. Bazrafshan, "Influences of solution chemistry on phenol removal from aqueous environments by electrocoagulation process using aluminium electrodes," Journal of Health Scope, vol. 1, no. 2, pp. 66-70, 2012.

[16] O. Abdelwahab, N. K. Amin, and E.-S. Z. El-Ashtoukhy, "Electrochemical removal of phenol from oil refinery wastewater," Journal of Hazardous Materials, vol. 163, no. 2-3, pp. 711-716, 2009.

[17] A. Dimoglo, H. Y. Akbulut, F. Cihan, and M. Karpuzcu, "Petrochemical wastewater treatment by means of clean electrochemical technologies," Clean Technologies and Environmental Policy, vol. 6, no. 4, pp. 288-295, 2004.

[18] M. H. El-Naas, M. A. Alhaija, and S. Al-Zuhair, "Evaluation of a three-step process for the treatment of petroleum refinery wastewater," Journal of Environmental Chemical Engineering, vol. 2, no. 1, pp. 56-62, 2014.

[19] A. Coelho, A. V. Castro, M. Dezotti, and G. L. Sant’Anna Jr., "Treatment of petroleum refinery sourwater by advanced oxidation processes," Journal of Hazardous Materials, vol. 137, no. 1, pp. 178-184, 2006.
[20] G. Salas and N. Ale, "Treatment of wastewaters from a pretroleum refinery through advanced oxidation (AOX), using reactive Fenton $\left(\mathrm{H}_{2} \mathrm{O}_{2} / \mathrm{Fe}^{2+}\right)$," Peruvian Magazine of Chemistry and Chemical Engineering, vol. 11, no. 2, pp. 12-18, 2008.

[21] S. Sayid, M. Abu, Z. Noor, S. Noor, and A. Aris, "Fenton and photo-fenton oxidation of sulfidic spent caustic: a comparative study based on statistical analysis," Environmental Engineering and Management Journal, vol. 13, no. 3, pp. 531-538, 2014.

[22] C. Comninellis, "Electrocatalysis in the electrochemical conversion/combustion of organic pollutants for waste water treatment," Electrochimica Acta, vol. 39, no. 11-12, pp. 1857-1862, 1994.

[23] V. S. de Sucre and A. P. Watkinson, "Anodic oxidation of phenol for waste water treatment," The Canadian Journal of Chemical Engineering, vol. 59, no. 1, pp. 52-59, 1981.

[24] B. Fleszar and J. Poszyńska, "An attempt to define benzene and phenol electrochemical oxidation mechanism," Electrochimica Acta, vol. 30, no. 1, pp. 31-42, 1985.

[25] H. Sharifian and D. W. Kirk, "Electrochemical oxidation of phenol," Journal of the Electrochemical Society, vol. 113, no. 5, pp. 921-924, 1986.

[26] I. F. McConvey, K. Scott, J. M. Henderson, and A. N. Haines, "Electrochemical reaction with parallel reversible surface adsorption: interpretations of the kinetics of anodic oxidation of aniline and phenol to carbon dioxide," Chemical Engineering and Processing: Process Intensification, vol. 22, no. 4, pp. 231-235, 1987.

[27] D.-T. Chin, N. R. K. Vilambi, and C. Y. Cheng, "Oxidation of phenol to benzoquinone in a CSTER with modulated alternating voltage," Journal of Applied Electrochemistry, vol. 19, no. 3, pp. 459-461, 1989.

[28] C. Comninellis and C. Pulgarin, "Anodic oxidation of phenol for waste water treatment," Journal of Applied Electrochemistry, vol. 21, no. 8, pp. 703-708, 1991.

[29] R. Kötz, S. Stucki, and B. Carcer, "Electrochemical waste water treatment using high overvoltage anodes. Part I: physical and electrochemical properties of $\mathrm{SnO}_{2}$ anodes," Journal of Applied Electrochemistry, vol. 21, no. 1, pp. 14-20, 1991.

[30] S. Stucki, R. Kötz, B. Carcer, and W. Suter, "Electrochemical waste water treatment using high overvoltage anodes. Part II: anode performance and applications," Journal of Applied Electrochemistry, vol. 21, no. 2, pp. 99-104, 1991.

[31] O. J. Murphy, G. D. Hitchens, L. Kaba, and C. E. Verostko, "Direct electrochemical oxidation of organics for wastewater treatment," Water Research, vol. 26, no. 4, pp. 443-451, 1992.

[32] C. Comninellis and C. Pulgarin, "Electrochemical oxidation of phenol for wastewater treatment using $\mathrm{SnO}_{2}$, anodes," Journal of Applied Electrochemistry, vol. 23, no. 2, pp. 108-112, 1993.

[33] K. T. Kawagoe and D. C. Johnson, "Electrocatalysis of anodic oxygen-transfer reactions. Oxidation of phenol and benzene at bismuth-doped lead dioxide electrodes in acidic solutions," Journal of the Electrochemical Society, vol. 141, no. 12, pp. 34043409, 1994.

[34] C. Comninellis and A. Nerini, "Anodic oxidation of phenol in the presence of $\mathrm{NaCl}$ for wastewater treatment," Journal of Applied Electrochemistry, vol. 25, no. 1, pp. 23-28, 1995.

[35] N. B. Tahar and A. Savall, "Mechanistic aspects of phenol electrochemical degradation by oxidation on a $\mathrm{Ta} / \mathrm{PbO}_{2}$ anode," Journal of the Electrochemical Society, vol. 145, no. 10, pp. 34273434, 1998.

[36] U. Schümann and P. Gründler, "Electrochemical degradation of organic substances at $\mathrm{PbO}_{2}$ anodes: monitoring by continuous 
$\mathrm{CO}_{2}$ measurements," Water Research, vol. 32, no. 9, pp. 28352842, 1998.

[37] N. B. Tahar and A. Savall, "Electrochemical degradation of phenol in aqueous solution on bismuth doped lead dioxide: a comparison of the activities of various electrode formulations," Journal of Applied Electrochemistry, vol. 29, no. 3, pp. 277-283, 1999.

[38] P. Cañizares, J. A. Domínguez, M. A. Rodrigo, J. Villaseñor, and J. Rodríguez, "Effect of the current intensity in the electrochemical oxidation of aqueous phenol wastes at an activated carbon and steel anode," Industrial \& Engineering Chemistry Research, vol. 38, no. 10, pp. 3779-3785, 1999.

[39] J. Iniesta, J. González-García, E. Expósito, V. Montiel, and A. Aldaz, "Influence of chloride ion on electrochemical degradation of phenol in alkaline medium using bismuth doped and pure $\mathrm{PbO}_{2}$ anodes," Water Research, vol. 35, no. 14, pp. 32913300, 2001.

[40] G. A. Bogdanovskii, T. V. Savel'eva, and T. S. Saburova, "Phenol conversions during electrochemical generation of active chlorine," Russian Journal of Electrochemistry, vol. 37, no. 8, pp. 865869, 2001.

[41] Z. Wu and M. Zhou, "Partial degradation of phenol by advanced electrochemical oxidation process," Environmental Science and Technology, vol. 35, no. 13, pp. 2698-2703, 2001.

[42] M. H. Zhou, Z. C. Wu, and D. H. Wang, "A novel electrocatalysis method for organic pollutants degradation," Chinese Chemical Letters, vol. 12, no. 10, pp. 929-932, 2001.

[43] R. T. Pelegrini, R. S. Freire, N. Duran, and R. Bertazzoli, "Photoassisted electrochemical degradation of organic pollutants on a DSA type oxide electrode: process test for a phenol synthetic solution and its application for the E1 bleach Kraft mill effluent," Environmental Science and Technology, vol. 35, no. 13, pp. 28492853, 2001.

[44] M.-H. Zhou, Z.-C. Wu, and X.-D. Xuan, "Anodic-cathodic electrocatalytic degradation of phenol with oxygen sparged in the presence of iron (II)," Chemical Research in Chinese Universities, vol. 18, no. 3, pp. 262-266, 2002.

[45] R. L. Pelegrino, R. A. Di Iglia, C. G. Sanches, L. A. Avaca, and R. Bertazzoli, "Comparative study of commercial oxide electrodes performance in electrochemical degradation of organics in aqueous solutions," Journal of the Brazilian Chemical Society, vol. 13, no. 1, pp. 60-65, 2002.

[46] Y. J. Feng and X. Y. Li, "Electro-catalytic oxidation of phenol on several metal-oxide electrodes in aqueous solution," Water Research, vol. 37, no. 10, pp. 2399-2407, 2003.

[47] P. D. P. Alves, M. Spagnol, G. Tremiliosi-Filho, and A. R. de Andrade, "Investigation of the influence of the anode composition of DSA-type electrodes on the electrocatalytic oxidation of phenol in neutral medium," Journal of the Brazilian Chemical Society, vol. 15, no. 5, pp. 626-634, 2004.

[48] P. Cañizares, J. García-Gómez, J. Lobato, and M. A. Rodrigo, "Modeling of wastewater electro-oxidation processes part I. General description and application to inactive electrodes," Industrial \& Engineering Chemistry Research, vol. 43, no. 9, pp. 1915-1922, 2004.

[49] P. Cañizares, J. García-Gómez, J. Lobato, and M. A. Rodrigo, "Modeling of wastewater electro-oxidation processes part II. Application to active electrodes," Industrial \& Engineering Chemistry Research, vol. 43, no. 9, pp. 1923-1931, 2004.
[50] D. Fino, C. C. Jara, G. Saracco, V. Specchia, and P. Spinelli, "Deactivation and regeneration of Pt anodes for the electrooxidation of phenol," Journal of Applied Electrochemistry, vol. 35, no. 4, pp. 405-411, 2005.

[51] X.-Y. Li, Y.-H. Cui, Y.-J. Feng, Z.-M. Xie, and J.-D. Gu, “Reaction pathways and mechanisms of the electrochemical degradation of phenol on different electrodes," Water Research, vol. 39, no. 10, pp. 1972-1981, 2005.

[52] M. Li, C. Feng, W. Hu, Z. Zhang, and N. Sugiura, "Electrochemical degradation of phenol using electrodes of Ti/ $\mathrm{RuO}_{2}-\mathrm{Pt}$ and $\mathrm{Ti} / \mathrm{IrO}_{2}$-Pt," Journal of Hazardous Materials, vol. 162, no. 1, pp. 455-462, 2009.

[53] E. Chatzisymeon, S. Ferro, I. Karafyllis, D. Mantzavinos, N. Kalogerakis, and A. Katsaounis, "Anodic oxidation of phenol on $\mathrm{Ti} / \mathrm{IrO}_{2}$ electrode: experimental studies," Catalysis Today, vol. 151, no. 1-2, pp. 185-189, 2010.

[54] Y. Yavuz and A. S. Koparal, "Electrochemical oxidation of phenol in a parallel plate reactor using ruthenium mixed metal oxide electrode," Journal of Hazardous Materials, vol. 136, no. 2, pp. 296-302, 2006.

[55] A. M. Z. Ramalho, C. A. Martínez-Huitle, and D. R. D. Silva, "Application of electrochemical technology for removing petroleum hydrocarbons from produced water using a DSAtype anode at different flow rates," Fuel, vol. 89, no. 2, pp. 531$534,2010$.

[56] M. R. G. Santos, M. O. F. Goulart, J. Tonholo, and C. L. P. S. Zanta, "The application of electrochemical technology to the remediation of oily wastewater," Chemosphere, vol. 64, no. 3, pp. 393-399, 2006.

[57] F. Montilla, E. Morallón, and J. L. Vázquez, "Evaluation of the electrocatalytic activity of antimony-doped tin dioxide anodes toward the oxidation of phenol in aqueous solutions," Journal of the Electrochemical Society, vol. 152, no. 10, pp. B421-B427, 2005.

[58] Z.-C. Wu, M.-H. Zhou, Z.-W. Huang, and D.-H. Wang, "Electrocatalysis method for wastewater treatment using a novel beta-lead dioxide anode," Journal of Zhejinag University Science, vol. 3, no. 2, pp. 194-198, 2002.

[59] M. Zhou, Q. Dai, L. Lei, C. Ma, and D. Wang, "Long life modified lead dioxide anode for organic wastewater treatment: electrochemical characteristics and degradation mechanism," Environmental Science and Technology, vol. 39, no. 1, pp. 363370, 2005.

[60] P.-A. Michaud, M. Panizza, L. Ouattara, T. Diaco, G. Foti, and C. Comninellis, "Electrochemical oxidation of water on synthetic boron-doped diamond thin film anodes," Journal of Applied Electrochemistry, vol. 33, no. 2, pp. 151-154, 2003.

[61] A. Kraft, M. Stadelmann, and M. Blaschke, "Anodic oxidation with doped diamond electrodes: a new advanced oxidation process," Journal of Hazardous Materials, vol. 103, no. 3, pp. 247261, 2003.

[62] B. Marselli, J. García-Gómez, P.-A. Michaud, M. A. Rodrigo, and C. Comninellis, "Electrogeneration of hydroxyl radicals on boron-doped diamond electrodes," Journal of the Electrochemical Society, vol. 150, no. 3, pp. D79-D83, 2003.

[63] J. Iniesta, P. A. Michaud, M. Panizza, G. Cerisola, A. Aldaz, and C. Comninellis, "Electrochemical oxidation of phenol at borondoped diamond electrode," Electrochimica Acta, vol. 46, no. 23, pp. 3573-3578, 2001.

[64] M. Panizza, P. A. Michaud, G. Cerisola, and C. Comninellis, "Electrochemical treatment of wastewaters containing organic pollutants on boron-doped diamond electrodes: prediction 
of specific energy consumption and required electrode area," Electrochemistry Communications, vol. 3, no. 7, pp. 336-339, 2001.

[65] P. L. Hagans, P. M. Natishan, B. R. Stoner, and W. E. O'Grady, "Electrochemical oxidation of phenol using boron-doped diamond electrodes," Journal of the Electrochemical Society, vol. 148, no. 7, pp. E298-E301, 2001.

[66] P. Cañizares, M. Díaz, J. A. Domínguez, J. García-Gómez, and M. A. Rodrigo, "Electrochemical oxidation of aqueous phenol wastes on synthetic diamond thin-film electrodes," Industrial \& Engineering Chemistry Research, vol. 41, no. 17, pp. 4187-4194, 2002.

[67] A. V. Diniz, N. G. Ferreira, E. J. Corat, and V. J. Trava-Airoldi, "Efficiency study of perforated diamond electrodes for organic compounds oxidation process," Diamond and Related Materials, vol. 12, no. 3-7, pp. 577-582, 2003.

[68] J.-F. Zhi, H.-B. Wang, T. Nakashima, T. N. Rao, and A. Fujishima, "Electrochemical incineration of organic pollutants on boron-doped diamond electrode, evidence for direct electrochemical oxidation pathway," The Journal of Physical Chemistry B, vol. 107, no. 48, pp. 13389-13395, 2003.

[69] A. M. Polcaro, A. Vacca, S. Palmas, and M. Mascia, "Electrochemical treatment of wastewater containing phenolic compounds: oxidation at boron-doped diamond electrodes," Journal of Applied Electrochemistry, vol. 33, no. 10, pp. 885-892, 2003.

[70] P. Cañizares, J. García-Gómez, C. Sáez, and M. A. Rodrigo, "Electrochemical oxidation of several chlorophenols on diamond electrodes. Part I. Reaction mechanism," Journal of Applied Electrochemistry, vol. 33, no. 10, pp. 917-927, 2003.

[71] P. Cañizares, J. García-Gómez, J. Lobato, and M. A. Rodrigo, "Electrochemical oxidation of aqueous carboxylic acid wastes using diamond thin-film electrodes," Industrial \& Engineering Chemistry Research, vol. 42, no. 5, pp. 956-962, 2003.

[72] A. Morão, A. Lopes, M. T. P. de Amorim, and I. C. Gonçalves, "Degradation of mixtures of phenols using boron doped diamond electrodes for wastewater treatment," Electrochimica Acta, vol. 49, no. 9-10, pp. 1587-1595, 2004.

[73] P. Cañizares, C. Sáez, J. Lobato, and M. A. Rodrigo, "Electrochemical oxidation of polyhydroxybenzenes on boron-doped diamond anodes," Industrial \& Engineering Chemistry Research, vol. 43, no. 21, pp. 6629-6637, 2004.

[74] P. Cañizares, J. Lobato, R. Paz, M. A. Rodrigo, and C. Sáez, "Electrochemical oxidation of phenolic wastes with borondoped diamond anodes," Water Research, vol. 39, no. 12, pp. 2687-2703, 2005.

[75] C. Flox, J. A. Garrido, R. M. Rodríguez et al., "Degradation of 4,6-dinitro-o-cresol from water by anodic oxidation with a boron-doped diamond electrode," Electrochimica Acta, vol. 50, no. 18, pp. 3685-3692, 2005.

[76] M. J. Pacheco, A. Morão, A. Lopes, L. Ciríaco, and I. Gonçalves, "Degradation of phenols using boron-doped diamond electrodes: a method for quantifying the extent of combustion," Electrochimica Acta, vol. 53, no. 2, pp. 629-636, 2007.

[77] M. Mascia, A. Vacca, S. Palmas, and A. M. Polcaro, "Kinetics of the electrochemical oxidation of organic compounds at BDD anodes: modelling of surface reactions," Journal of Applied Electrochemistry, vol. 37, no. 1, pp. 71-76, 2007.

[78] X. Zhu, S. Shi, J. Wei et al., "Electrochemical oxidation characteristics of $p$-substituted phenols using a boron-doped diamond electrode," Environmental Science and Technology, vol. 41, no. 18, pp. 6541-6546, 2007.
[79] C. Flox, P.-L. Cabot, F. Centellas et al., "Solar photoelectroFenton degradation of cresols using a flow reactor with a borondoped diamond anode," Applied Catalysis B: Environmental, vol. 75, no. 1-2, pp. 17-28, 2007.

[80] M. Mascia, A. Vacca, A. M. Polcaro, S. Palmas, J. R. Ruiz, and A. da Pozzo, "Electrochemical treatment of phenolic waters in presence of chloride with boron-doped diamond (BDD) anodes: experimental study and mathematical model," Journal of Hazardous Materials, vol. 174, no. 1-3, pp. 314-322, 2010.

[81] X. Zhu, J. Ni, H. Li, Y. Jiang, X. Xing, and A. G. L. Borthwick, "Effects of ultrasound on electrochemical oxidation mechanisms of $p$-substituted phenols at $\mathrm{BDD}$ and $\mathrm{PbO}_{2}$ anodes," Electrochimica Acta, vol. 55, no. 20, pp. 5569-5575, 2010.

[82] X. Zhu, J. Ni, J. Wei, X. Xing, H. Li, and Y. Jiang, "Scale-up of BDD anode system for electrochemical oxidation of phenol simulated wastewater in continuous mode," Journal of Hazardous Materials, vol. 184, no. 1-3, pp. 493-498, 2010.

[83] J. Wei, X. Zhu, and J. Ni, "Electrochemical oxidation of phenol at boron-doped diamond electrode in pulse current mode," Electrochimica Acta, vol. 56, no. 15, pp. 5310-5315, 2011.

[84] J. Sun, H. Lu, H. Lin et al., "Electrochemical oxidation of aqueous phenol at low concentration using Ti/BDD electrode," Separation and Purification Technology, vol. 88, pp. 116-120, 2012.

[85] J. Lv, Y. Feng, J. Liu, Y. Qu, and F. Cui, "Comparison of electrocatalytic characterization of boron-doped diamond and $\mathrm{SnO}_{2}$ electrodes," Applied Surface Science, vol. 283, pp. 900-905, 2013.

[86] G. Hurwitz, P. Pornwongthong, S. Mahendra, and E. M. V. Hoek, "Degradation of phenol by synergistic chlorineenhanced photo-assisted electrochemical oxidation," Chemical Engineering Journal, vol. 240, pp. 235-243, 2014.

[87] X. Chen, G. Chen, F. Gao, and P. L. Yue, "High-performance Ti/BDD electrodes for pollutant oxidation," Environmental Science and Technology, vol. 37, no. 21, pp. 5021-5026, 2003.

[88] X. Chen, F. Gao, and G. Chen, "Comparison of Ti/BDD and $\mathrm{Ti} / \mathrm{SnO}_{2}-\mathrm{Sb}_{2} \mathrm{O}_{5}$ electrodes for pollutant oxidation," Journal of Applied Electrochemistry, vol. 35, no. 2, pp. 185-191, 2005.

[89] E. Weiss, K. Groenen-Serrano, and A. Savall, "A comparison of electrochemical degradation of phenol on boron doped diamond and lead dioxide anodes," Journal of Applied Electrochemistry, vol. 38, no. 3, pp. 329-337, 2008.

[90] A. Medel, E. Bustos, K. Esquivel, L. A. Godínez, and Y. Meas, "Electrochemical incineration of phenolic compounds from the hydrocarbon industry using boron-doped diamond electrodes," International Journal of Photoenergy, vol. 2012, Article ID 681875, 6 pages, 2012.

[91] J. H. Bezerra, M. M. Soares, N. Suely, D. Riveiro, and C. A. Martínez-Huitle, "Application of electrochemical oxidation as alternative treatment of produced water generated by Brazilian petrochemical industry," Fuel, vol. 96, pp. 80-87, 2012.

[92] A. J. C. da Silva, E. V. dos Santos, C. C. D. O. Morais, C. A. Martínez-Huitle, and S. S. L. Castro, "Electrochemical treatment of fresh, brine and saline produced water generated by petrochemical industry using $\mathrm{Ti} / \mathrm{IrO}_{2}-\mathrm{Ta}_{2} \mathrm{O}_{5}$ and $\mathrm{BDD}$ in flow reactor," Chemical Engineering Journal, vol. 233, pp. 47-55, 2013.

[93] R. B. A. Souza and L. A. M. Ruotolo, "Electrochemical treatment of oil refinery effluent using boron-doped diamond anodes," Journal of Environmental Chemical Engineering, vol. 1, no. 3, pp. 544-551, 2013. 
[94] A. Medel, E. Bustos, L. M. Apátiga, and Y. Meas, "Surface activation of $\mathrm{C}-\mathrm{sp}^{3}$ in Boron-Doped diamond electrode," Electrocatalysis, vol. 4, no. 4, pp. 189-195, 2013.

[95] Mexican Regulation NMX-AA-050-SCFI-2001, "Analysis of water-determination of total phenols in natural, potable, residual and treated residual waters," 2001.

[96] A. Fakhru'l-Razi, A. Pendashteh, L. C. Abdullah, D. R. A. Biak, S. S. Madaeni, and Z. Z. Abidin, "Review of technologies for oil and gas produced water treatment," Journal of Hazardous Materials, vol. 170, no. 2-3, pp. 530-551, 2009.

[97] L. Wei, S. Guo, G. Yan, C. Chen, and X. Jiang, "Electrochemical pretreatment of heavy oil refinery wastewater using a threedimensional electrode reactor," Electrochimica Acta, vol. 55, no. 28, pp. 8615-8620, 2010.

[98] E. V. dos Santos, S. F. M. Sena, D. R. da Silva, S. Ferro, A. de Battisti, and C. A. Martínez-Huitle, "Scale-up of electrochemical oxidation system for treatment of produced water generated by Brazilian petrochemical industry," Environmental Science and Pollution Research, vol. 21, pp. 8466-8475, 2014.

[99] M. Murugananthan, S. S. Latha, G. B. Raju, and S. Yoshihara, "Role of electrolyte on anodic mineralization of atenolol at boron doped diamond and Pt electrodes," Separation and Purification Technology, vol. 79, no. 1, pp. 56-62, 2011.

[100] A. Sánchez-Carretero, C. Sáez, P. Cañizares, and M. A. Rodrigo, "Electrochemical production of perchlorates using conductive diamond electrolyses," Chemical Engineering Journal, vol. 166, no. 2, pp. 710-714, 2011.

[101] Official Mexican Regulation NOM-001-SEMARNAT-1996, "Maximum limits allowed of pollutants in discharges of wastewaters and national resources," 1996.

[102] B. F. Giannetti, W. A. Moreira, S. H. Bonilla, C. M. V. B. Almeida, and T. Rabóczkay, "Towards the abatement of environmental mercury pollution: an electrochemical characterization," Colloids and Surfaces A: Physicochemical and Engineering Aspects, vol. 276, no. 1-3, pp. 213-220, 2006.

[103] U. Skyllberg, P. R. Bloom, J. Qian, C.-M. Lin, and W. F. Bleam, "Complexation of mercury(II) in soil organic matter: EXAFS evidence for linear two-coordination with reduced sulfur groups," Environmental Science and Technology, vol. 40, no. 13, pp. 4174-4180, 2006.

[104] D. T. Cestarolli and A. R. de Andrade, "Electrochemical oxidation of phenol at $\mathrm{Ti} / \mathrm{Ru}_{0.3} \mathrm{~Pb}_{(0.7-x)} \mathrm{Ti}_{x} \mathrm{O}_{y}$ electrodes in aqueous media," Journal of the Electrochemical Society, vol. 154, no. 2, pp. E25-E30, 2007.

[105] S. Balaji, S. J. Chung, R. Thiruvenkatachari, and I. S. Moon, "Mediated electrochemical oxidation process: electro-oxidation of cerium(III) to cerium(IV) in nitric acid medium and a study on phenol degradation by cerium(IV) oxidant," Chemical Engineering Journal, vol. 126, no. 1, pp. 51-57, 2007.

[106] D. Reyter, D. Bélanger, and L. Roué, "Nitrate removal by a paired electrolysis on copper and $\mathrm{Ti} / \mathrm{IrO}_{2}$ coupled electrodesinfluence of the anode/cathode surface area ratio," Water Research, vol. 44, no. 6, pp. 1918-1926, 2010.

[107] B. H. Diya'Uddeen, W. M. A. W. Daud, and A. R. Abdul Aziz, "Treatment technologies for petroleum refinery effluents: a review," Process Safety and Environmental Protection, vol. 89, no. 2, pp. 95-105, 2011. 

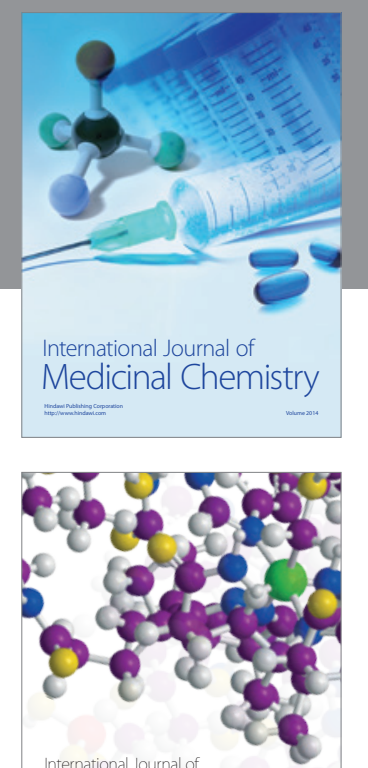

\section{Carbohydrate} Chemistry

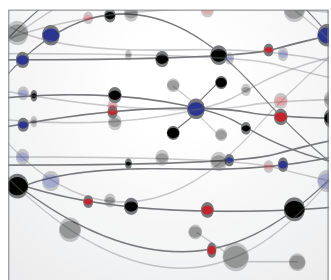

The Scientific World Journal
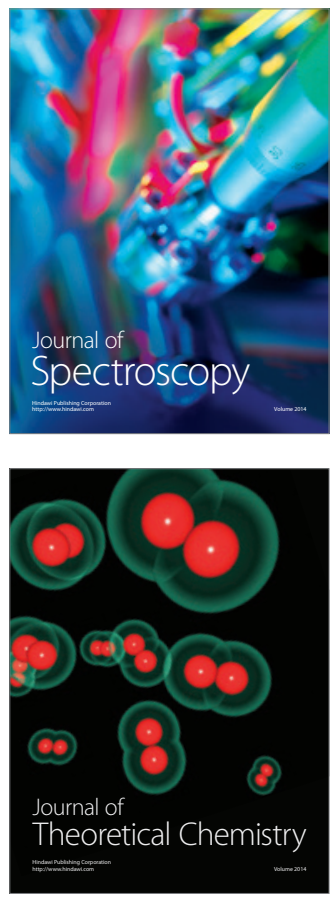
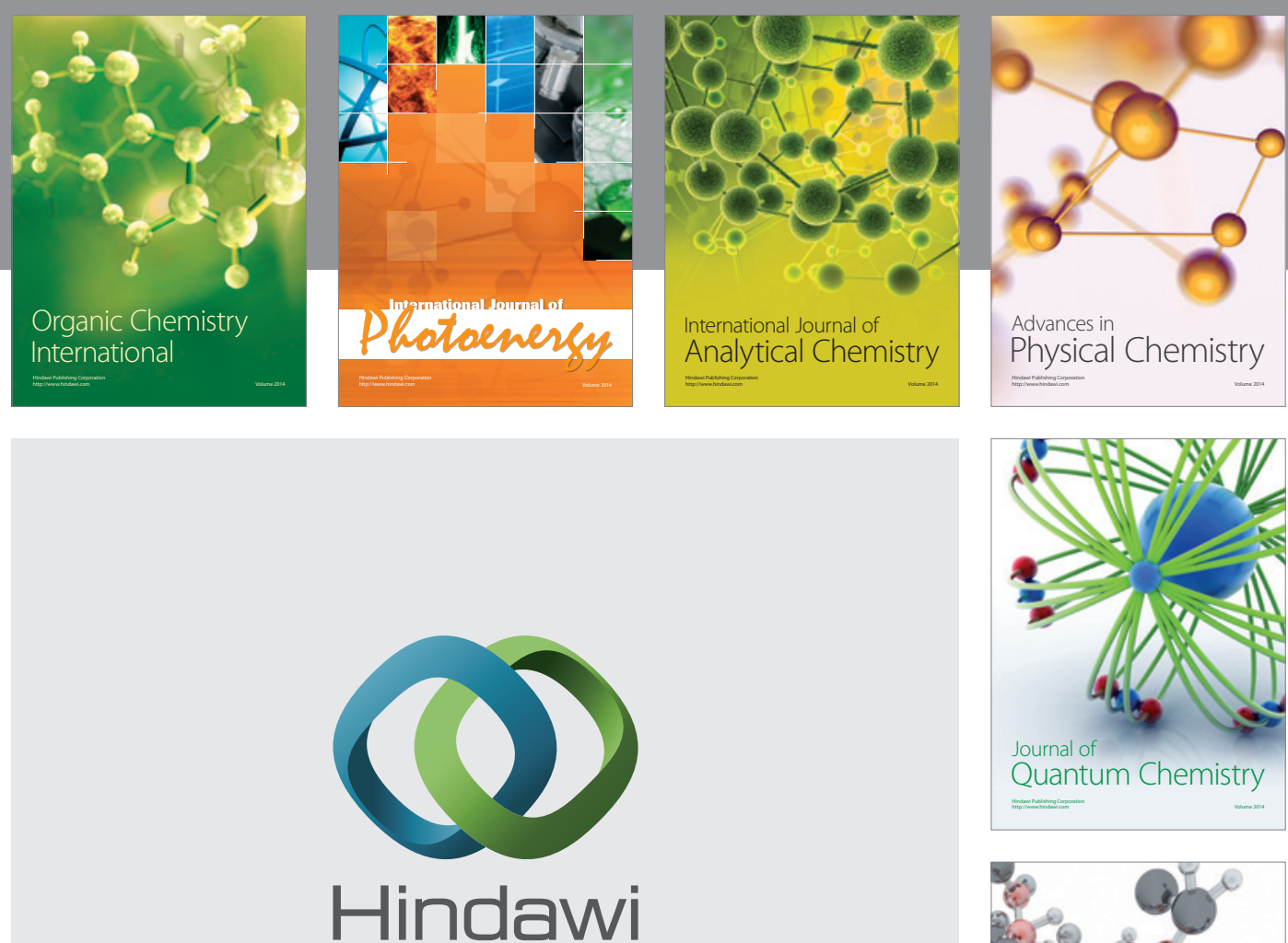

Submit your manuscripts at

http://www.hindawi.com

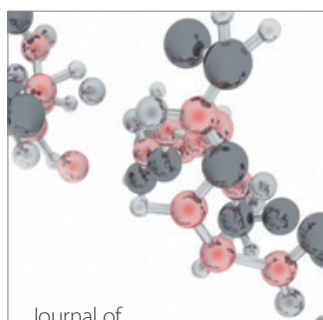

Analytical Methods

in Chemistry

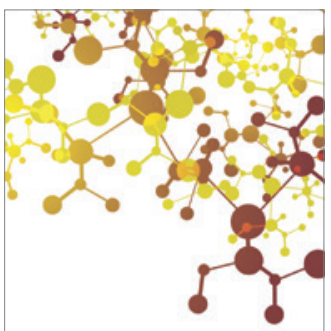

Journal of

Applied Chemistry

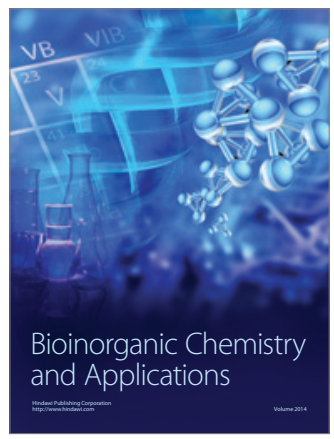

Inorganic Chemistry
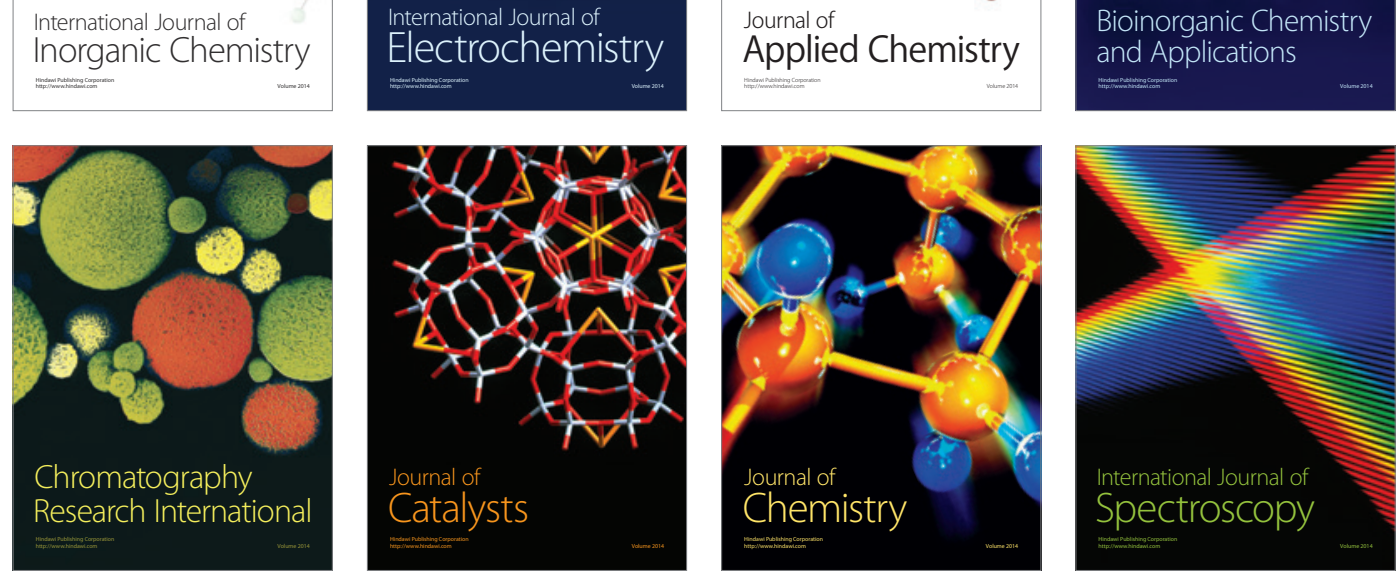